\title{
PRESENT BIAS AND UNDERINVESTMENT IN EDUCATION? LONG-RUN EFFECTS OF CHILDHOOD EXPOSURE TO BOOMS IN COLOMBIA
}

\author{
Bladimir Carrillo
}

\section{LATIN AMERICAN AND THE CARIBBEAN ECONOMIC ASSOCIATION}

\author{
March 2019
}

The views expressed herein are those of the authors and do not necessarily reflect the views of the Latin American and the Caribbean Economic Association. Research published in this series may include views on policy, but LACEA takes no institutional policy positions.

LACEA working papers are circulated for discussion and comment purposes. Citation of such a paper should account for its provisional character. A revised version may be available directly from the author.

(C) 2019 by Bladimir Carrillo. All rights reserved. Short sections of text, not to exceed two paragraphs, may be quoted without explicit permission provided that full credit, including $\odot$ notice, is given to the source. 
LACEA WORKING PAPER SERIES No. 0025 March 2019

Present Bias and Underinvestment in Education? Long-run Effects of Childhood Exposure to Booms in Colombia

Bladimir Carrillo

Department of Rural Economics, Universidade Federal de Viosa

bladimir.bermudez@ufv.br

\begin{abstract}
This paper examines the long-run impacts of income shocks by exploiting variation in coffee cultivation patterns within Colombia and world coffee prices during cohorts' school-going years in a differences-in-differences framework. The results indicate that cohorts who faced higher returns to coffee-related work during school-going years completed fewer years of schooling and have lower income in adulthood. These findings suggest that leaving school during temporary booms results in a significant loss of long-term income. This is consistent with the possibility that students may ignore or heavily discount the future consequences of dropout decisions when faced with immediate income gains.
\end{abstract}

JEL Classification: J24; O12; O13.

Keywords: Coffee price shocks, transitory income shocks, human capital accumulation, opportunity cost of schooling, long-run impacts, schooling.

\title{
ACKNOWLEDGEMENTS AND FINANCIAL DISCLOSURE
}

I thank David Atkin, Carlos Charris, Raj Chetty, Rafael Corbi, Eduardo Correia, Sergio Firpo, Luis Galvis, Naercio Menezes, Renata Narita, Mathew Notowidigdo, Philips Oreopoulos, Breno Sampaio, Gustavo Sampaio, Marcelo Santos, Jesse Shapiro, Juan Trujillo, Ian Trotter, Paul Vaz, Raul Velilla, and seminar participants at various conferences and seminars for helpful comments and suggestions. I am especially grateful to Grant Miller and Piedad Urdinola for kindly sharing their data on coffee cultivation. I am solely responsible for this paper's contents. 


\section{Introduction}

How aggregate income shocks affect human capital is a question of central importance to both policymakers and economists. Improvements in economic conditions can facilitate the accumulation of human capital by making education more affordable, but at the same time higher wages can significantly raise the opportunity cost of schooling and thus discourage educational investments. A large body of work provides important evidence that economic booms are generally associated with poorer contemporaneous school outcomes, including enrollment, dropout, and grade attained by the end of a specific year (e.g., Black et al., 2005; Edmonds et al., 2010). ${ }^{1}$ To date, however, there is little systematic evidence documenting the extent to which these shocks translate into long-run differences in total human capital, and much less evidence on how they affect subsequent labor market success in adulthood.

There are multiple reasons why short-run and long-run impacts of income shocks on human capital formation may not be the same. While existing literature generally documents that child enrollment declines during booms, this will not affect completed human capital unless individuals continue to make different educational choices even after these episodes. Children interrupting school and taking up employment opportunities during temporary booms may simply return to school after these economic opportunities are gone. ${ }^{2}$ This will alter the timing of schooling without any consequence on completed education. Furthermore, many youths may delay schooling and enter the workforce during booms to accumulate savings and finance subsequent education that otherwise would have been unaffordable (Lochner and Monge-Naranjo, 2012; Johnson, 2013). As a result, the total accumulation of human capital could be unaffected or even increase over the long run. Alternatively, delaying or interrupting schooling may discourage later educational investments if schooling at critical ages raises the productivity of investments at subsequent stages (Cunha and Heckman, 2007). This may lead to larger long-run impacts of income shocks.

This paper examines this question by exploring the long-term effects of plausibly exogenous income shocks in Colombia generated by changes in world coffee prices. Colombia is a major exporter of coffee, a relatively homogeneous good whose price in international

\footnotetext{
${ }^{1}$ Other studies include Ferreira and Schady (2004), Kruger (2007), Rosenzweig and Evenson (1977), and Soares et al. (2012). A comprehensive review of this literature can be found in Ferreira and Schady (2009). These studies do not always find countercyclical patterns. For example, Thomas et al. (2004) show that the 1998 Indonesian crisis was associated with significant reductions in school enrollment.

${ }^{2}$ For example, Light (1995) reports that a significant fraction of individuals who leave school end up returning to school later in the United States. Similarly, Annan et al. (2011) find high returning rates among youths who were recruited temporarily by the Army in Uganda.
} 
markets is an important determinant of household incomes in coffee-growing areas. ${ }^{3}$ From the mid-1950s to the mid-1990s, several events caused sudden and dramatic fluctuations in coffee prices, including weather shocks that decimated Brazilian coffee crops, the collapse of the international coffee price agreement, and the unprecedented expansion in Vietnam's coffee industry. During this period, the real price of coffee fluctuated between 55 percent below and 130 percent above its historical average, and previous studies have documented that these shocks significantly affected local wages across coffee-growing areas (Miller and Urdinola, 2010; Dube and Vargas, 2013). Since all these events originated outside of Colombia, they created shocks to income virtually independent of local schooling decisions.

To examine the long-run impacts of these shocks, I combine historical data on predetermined coffee cultivation patterns across municipalities with the timing of coffee price shocks in a differences-in-differences strategy. Colombia is a geographically heterogeneous country, such that, some regions are well suited for coffee cultivation, while others are not. Individuals in areas where the intensity of coffee cultivation is high should be more affected by changes in coffee prices, but those in low-intensity or non-growing areas serve as a comparison group. In addition, because the coffee price shocks were large and of varying intensities, different birth cohorts witnessed different world coffee market conditions during their school-going years. The empirical strategy therefore compares cohorts based on the intensity of coffee cultivation in their place of birth, and world coffee prices during their schooling-going years. This strategy identifies an intention-to-treat effect under the assumption that trends in outcomes would have been similar in areas with varying coffee cultivation patterns in the absence of coffee price shocks. I provide evidence supporting the plausibility of this assumption.

The research design has two key features that enable me to make stronger inferences about the long-run impacts of income shocks and potential mechanisms than previous studies. First, coffee represents an insignificant component of the total household budget and it is not a health input, so it is unlikely to have a direct effect on outcomes. This is in sharp contrast with previous work focusing on staple agricultural crops (Beegle et al., 2009) and rainfall shocks (Shah and Steinberg, 2017). ${ }^{4}$ Second, the Colombian government does not

\footnotetext{
${ }^{3}$ Although coffee beans are a relatively homogeneous good, there are some sub-varieties that differ in terms of size, color, resistance to pest and diseases, and conditions required for cultivation. Colombia is a major producer of washed arabica coffee, the most popular variety of coffee. This variety contains less caffeine when compared to robusta coffee (the second most popular variety of coffee), which yields some differences in flavor. For more details on the coffee industry, see Macchiavello and Morjaria (2017) and Blouin and Macchiavello (forthcoming).

${ }^{4}$ In particular, while heavy rainfall and droughts can influence agricultural income, they can also affect environmental sanitary conditions and the prevalence of mosquito vectors that transmit a number of diseases, all of which are likely to have an independent effect on human capital formation (Maccini and Yang, 2009; Rocha and Soares, 2015)
} 
tax coffee production and thus coffee market conditions are not linked to the financing of local public spending. ${ }^{5}$ This provides an unusual opportunity to more directly evaluate the relative role of the opportunity cost of schooling and household income compared to previous literature. ${ }^{6}$ Since both mechanisms are of the opposite sign, reduced-form estimates provide a test about their relative importance in the production function of human capital.

The estimates suggest that a rise in international coffee prices reduces educational attainment disproportionally in municipalities cultivating more coffee. The estimates imply that the increase in childhood coffee prices from individuals born in 1954 (preboom cohort) to those born in 1970 (boom cohort) led to a decline in completed schooling of 0.045 years. This estimate is very precise and of comparable magnitude to that of well-documented interventions targeting education in developing countries. For example, the magnitude of this effect is quite similar to those produced by the Colombian PACES program, which randomly assigned private school vouchers (Angrist et al., 2002).

I show that these results are robust with respect to an array of different specifications. For example, allowing for flexible and differential trends, parameterized as a function of a number of baseline characteristics (i.e., the incidence of specific diseases, early internal conflict, and measures of general economic development), has no discernible impact on the baseline estimate. A model that uses Brazilian coffee production levels as an instrument for international coffee prices gives comparable estimates to the baseline model. This is consistent with the notion that the major coffee market shocks were result of abrupt changes in Brazilian supply. Finally, there are no differential changes in schooling across municipalities with different coffee cultivation intensities for cohorts exposed in childhood to stable coffee prices.

These findings suggest the primacy of the opportunity cost of schooling over income in determining long-run human capital. Several pieces of evidence support this interpretation. Further specifications that consider exposure at different ages reveal that the timing of the effects coincides with that of schooling decisions. Data on child outcomes show that children are more likely to work and less likely to stay in school during coffee booms. Additionally, the child labor and schooling results are significantly larger and more precisely estimated for men than for women. These gender-specific effects are more likely to be driven by girls being less responsive to the same changes in the same coffee-related work opportunities than

\footnotetext{
${ }^{5}$ Miller and Urdinola (2010) provide evidence consistent with this view by showing that coffee price shocks are not associated with changes in local tax revenue and public spending.

${ }^{6}$ Some previous studies have investigated the impacts of oil production on schooling in the United States (Emery et al., 2012). However, this commodity is generally heavily taxed and linked to the financing of local public spending on education and health (Acemoglu et al., 2013), so the role of household income is not clear.
} 
factors that only affect general human capital formation, such as changes in the quality of schools. Finally, I provide additional evidence that helps rule out alternative potential mechanisms, including changes in the supply of teachers, local violence, and household work decisions.

After establishing that coffee price shocks have a robust effect on completed education and the likely mechanism behind these patterns, I then examine potential changes in labor market earning profiles in adulthood. Work at earlier ages may provide some benefits, including acquisition of specific skills, increased social capital, and general work experience, that may be rewarded later in the labor market. If these potential rewards are large relative to income losses from leaving school "too soon", then one could observe positive overall impacts on subsequent labor market prospects. I find that individuals who faced coffee booms when they were of school-going age are in lower-paid occupations. The main estimate suggests that the increase in coffee prices from cohorts born in 1954 to those born in 1970 resulted in a 0.45 -percent reduction in earnings. Combined with the schooling results, this finding suggests that a one year decrease in schooling as result of a coffee boom would reduce adult earnings by about 10 percent.

Existing research suggests that these patterns are not obvious. In a simple model where education is entirely viewed as a financial investment, forward-looking students would not have incentives to leave school if the gains from early work are small relative to the benefits from schooling (Becker, 1962; Eckstein and Wolpin, 1999). However, my findings showing negative effects on long-run schooling and income are difficult to reconcile with this view. Rather, these results are consistent with the possibility that students ignore or heavily discount the future. In particular, it may be that individuals drop out of school when faced with immediate income gains without realizing that in a few years their salaries will be lower than if they had stayed at school. This possibility is made somewhat more plausible by the evidence in neurology that executive brain functions responsible for abstract reasoning, self-control and patience skills are underdeveloped among children and adolescents (Fuster, 2002; Giedd et al., 2010; Romine and Reynolds, 2005; Teffer and Semendeferi, 2012). A lack of these skills may lead youths to overemphasize immediate rewards and make decisions that lead to suboptimal outcomes (Lavecchia et al., 2016). This possible interpretation of the findings is consistent with previous studies showing that compulsory-schooling laws lead to improvements in a number of lifetime outcomes (Lochner and Moretti, 2004; Lleras-Muney, 2005; Oreopoulos, 2007).

The results of this paper provide novel evidence that educational decisions made early in life based on local labor market conditions can have persistent impacts. They build on and 
relate to several previous studies. ${ }^{7}$ Atkin (2016) documents that the arrival of formal jobs during years of substantial expansions in export-manufacturing industries in Mexico led to reduced school attendance and lower educational attainment, although it had no overall impacts on subsequent labor market income. An important distinction is that Atkin (2016) focuses on large formal firms, which provide valuable on-the-job-training opportunities and skill accumulation that may offset income losses from reduced formal schooling. This paper contributes by providing evidence that different labor market shocks are likely to have different long-run implications. Charles et al. (Forthcoming) show that the housing boom during the 2000s reduced college attendance among young adults and this decline was not completely reversed years later, providing suggestive evidence that these shocks may have permanently affected college education in the United States. However, it is unclear the extent to which findings in industrialized settings generalize to human capital formation in less developed countries. In countries with poor enforcement of child labor laws and absence of well-functioning credit markets, changes in economic conditions are likely to play a prominent role in early educational decisions of youths.

There are also a few studies that focus on the long-run effects of macroeconomic crises or big one-off shocks, although the evidence is much more mixed (Stuart, 2017; Ferreira and Schady, 2004; Funkhouser, 1999). This is perhaps unsurprising given that macroeconomic crises are a multifaceted treatment - for example they are generally associated with a collapse in public spending (including that on education). Furthermore, severe recessions in fragile states are generally preceded by political chaos, disruptions in institutions, and civil conflict, so before-after-like comparisons are difficult to interpret. ${ }^{8}$ In contrast, the specific features of the natural experiment employed in this paper provide a cleaner identification of long-run impacts of income shocks and at the same time allow me to focus on more specific mechanisms. In particular, the variation I exploit helps to more directly test the relative importance of household income versus time in the production of human capital.

This paper is also connected to a broad literature on the determinants of human capital formation. This literature has focused on the effects of changes in school supply (Duflo, 2001), school quality (Chetty et al., 2011a, 2014), conditional-cash transfer interventions

\footnotetext{
${ }^{7}$ A recent work by Sviatschi (2019) uses a similar strategy to analyze how exposure to illegal markets in adolescence affects the decision to enter crime, finding that this exposure leads to higher incarceration rates in adulthood. She also finds evidence of reduced school attendance, but it is unclear whether this result is a direct consequence of increased violence in areas where illegal activities are more prevalent rather than an opportunity cost effect.

${ }^{8}$ For example, the Peruvian macroeconomic crisis between 1988 and 1990, the focus of Ferreira and Schady (2004), was preceded by a period of major political instability, institutional collapse, and rapid expanding civil war. The expansion of guerrilla campaigns resulted in the control of most rural areas, leading to a state of emergency that caused massive rural-urban migration, shut down markets, and disrupted infrastructure (Crabtree, 2016).
} 
(Behrman et al., 2009, 2011), tuition fees policies (Angrist et al., 2002; Hübner, 2012), neighborhood characteristics (Chetty and Hendren, 2018), and school-based health interventions (Baird et al., 2016). This study is more directly related to previous studies linking economics shocks and child labor in developing countries (Edmonds and Pavcnik, 2005, 2006; Kruger, 2007; Edmonds et al., 2010; Soares et al., 2012). The findings of this paper add to this literature by documenting the extent to which economic shocks that increase child labor have persistent impacts.

Finally, this study also relates to the "resource curse" literature, which suggests that mineral and agricultural resource abundance may be bad for development (Sachs and Warner, 1995). This literature has generally emphasized the effects of commodity booms on institutions (Sala-i-Martin and Subramanian, 2003; Hausmann and Rigobon, 2003; Tsui, 2010), and recently on civil conflicts (Angrist and Kugler, 2008; Dube and Vargas, 2013). The results from the present study suggest that reduced long-run human capital is a less explored channel by which agricultural resource abundance may hamper development and economic growth.

The rest of the paper is organized as follows. Section 2 provides background information about coffee and the boom and bust episodes analyzed in this study. Section 3 describes data sources. Section 4 presents the empirical strategy. Section 5 shows the main results of the effect of coffee price shocks on long-run human capital and discusses alternative explanations for the main results. Finally, Section 6 concludes. Further results and robustness checks are presented in the online Appendix.

\section{Background}

\subsection{Coffee Cultivation in Colombia}

Colombia has traditionally grown coffee since at least $1835 .{ }^{9}$ Coffee cultivation requires quite specific geographic and climatic conditions. The most suitable areas for growing coffee in Colombia are those located on hillsides, with a steep slope and intense rain. Ideal climatic conditions include temperatures between 15 and 24 Celsius degrees, annual rainfall ranging from 1500 to 2000 millimeters, and relative humidity between 70 and 90 percent (Clifford and Wilson, 1985). In general, areas satisfying these conditions are found in the departments of Antioquia, Caldas, Quindío, Valle del Cauca, and Risaralda. ${ }^{10}$ As a result, coffee production tends to be geographically concentrated in these areas (see Figure 1). Since rain regimes vary across regions, Colombia is a particular case where coffee is harvested in

\footnotetext{
${ }^{9}$ Miller and Urdinola (2010) provide detailed description about coffee production in Colombia. Here, I capitalize and summarize their excellent review.

${ }^{10}$ Departments are a first-order administrative division, similar to a state in the United States.
} 
two different periods each year. The first harvest is typically from April through May, while the second one is from April to May.

Coffee farming is a time- and labor-intensive process in Colombia. Harvest is performed by hand because coffee trees are grown on rough and steep terrains, which do not allow mechanical picking of coffee beans. Because coffee cherries do not ripen evenly, the mature berries must be picked selectively. This can require visiting a single tree several times during one or two weeks until all berries are picked. Given that this is the most timeintensive process, it is perhaps unsurprising that about 60 percent of the labor force in the coffee sector are workers whose job is exclusively picking coffee beans during harvest time (Echeverry et al., 2013; United Nations Development Program, 2014).

The berries should be processed within a few hours of picking to ensure the best quality. In Colombia, the wet method is generally used to process coffee cherries (Giovannucci et al., 2002). The cherries are initially separated from other byproducts, such as pulp and skin, using pulping machines. The beans are then separated by size and placed in a water tank for one or two days to remove any layer of mucilage and make the beans rougher. Next, the beans are spread out on a surface to dry in the sun, which may take several weeks depending on weather conditions. Finally, the processed beans are sorted by size/weight and collected in sacks of 60 to 70 kilograms to control the moisture level and store the beans up to one year. Distributors buy the processed beans and then export and sell to roasters.

Coffee was Colombia's chief export product throughout much of the twentieth century. In the 1970s, the entire industry, including processing and transporting, accounted for as much as 30 percent of total agricultural GDP (Giovannucci et al., 2002). Most coffee farms are small, occupying an average of six hectares of land, and therefore much of the nonharvest processes are performed by their families. Conversely, large farmers rely on day laborers for the purposes of nonharvest maintenance. Because picking coffee cherries is a laborintensive process, both small and large farmers generally hire significant additional labor during harvest seasons.

Several reports and qualitative studies have found evidence that coffee farms informally hire children, and some indicate that many of them begin to help in the fields at age 5 (Bacca, 2015; Gómez, 2013; National Federation of Coffee Growers, 2011; Bernal and Cárdenas, 2006). A survey conducted in coffee-growing regions by the National Federation of Coffee Growers (NFCG) suggests that approximately one in four children participate in the coffee industry (National Federation of Coffee Growers, 2011). Bernal and Cárdenas (2006) document that this is the agricultural sector with the highest participation of children between 5 and 16 years old, with employment rates among boys that are twice as large as 
that among girls. ${ }^{11}$ Indeed, the Office of International Labor Affairs (ILA) included the Colombian coffee on the list of "products produced by child labor" (ILA, 2009). ${ }^{12}$

Picking coffee cherries is the main task performed by children involved in the coffee sector. Since it does not require physical strength or complex knowledge, it is suited even for young children. The task of a coffee picker is basically to harvest mature bright red coffee cherries and place them one by one into a basket. Qualitative studies generally find children as young as 5 or 6 years of age performing this activity (Gómez, 2013). These young children generally perform this task under supervision of older children or adults. The participation of children can be important because it allows adults to spend more time on other activities that require more physical effort and ability.

Sorting the larger from the smaller beans is also a harmless and relatively simple task that can be performed by children who are 7 years old. In contrast, carrying sacks is more suitable for older children (ages 12 to 16 years of age). This activity implies carrying sacks that weigh between 40 and 100 pounds to a place where the coffee cherries begin their transformation into beans. During the processing of the cherries, children may help by placing the cherries in the manual pulping machines and spreading the beans out on a surface for drying. Both tasks are relatively simple and can be performed by children around 7 years of age. However, while operating the pulping machines is also relatively simple, it involves more physical effort and thus is suitable for older children (those over 12 years of age).

During non-harvest seasons, there are fewer tasks that are suitable for children. Children over 10 years of age may help in pruning and cutting back old trees. However, the participation of children is likely to be less frequent in these types of activities as these are relatively difficult tasks that demand a lot of effort and in some cases can be harmful for children - for example pruning and cutting back old trees involve the use of machetes. Overall, while the type of tasks that children can perform vary with age, the most laborintensive and important one (that is, picking coffee cherries) can be easily performed both

\footnotetext{
${ }^{11}$ Bernal and Cárdenas (2006) find that the overall fraction of rural children between 5 and 16 years working in the coffee sector is about 7 percent. They also report sex ratios in this sector, which suggest that the rate of child labor in the coffee industry is 8 percent for boys and 4 percent for girls. However, these are aggregate figures that do not account for the fact that child labor in this agricultural sector is limited to coffee-growing regions. After adjusting for the share of rural population 5-16 years old in coffee growingareas, the fraction of children working in the coffee sector is about 15 percent, a figure that is somewhat lower than that reported by the National Federation of Coffee Growers. The corresponding adjusted figure is 20 percent for boys and 10 percent for girls.

${ }^{12}$ In response, the Colombian government have recently implemented some programs designed to reduce the prevalence of child labor in the coffee industry. One of these initiatives is the "Colombian Avanza" project, launched in 2017, which seeks to promote awareness and education campaigns on the importance of preventing child labor in coffee-growing areas (Partners of the Americas, 2018).
} 
by young and old children.

Although the most labor-intensive tasks occur during harvest seasons, the school cycle overlaps with these seasons. Indeed, the academic year in Colombia starts in February and ends in December, with a break of about 20 days in June. This means that about 30 percent of the academic year coincides with the harvest seasons. Hence, work during harvest time may significantly affect school attendance. In addition, since the first harvest occurs around the first months of the year, enrollment decisions may also be influenced by the returns to coffee work.

\subsection{National Federation of Coffee Growers}

The prominence of coffee in the Colombian economy led to the creation of the National Federation of Coffee Growers (NFCG) in 1927, an industrial organization that seeks to advance the interests of coffee farmers. Following its creation, Law 76/1927 gave the NFCG the authority to administer and manage all revenue generated from coffee exports. The organization directly charges an "export tax" to coffee producers, and the national government transfers any other revenue generated by coffee production to the NFCG. These resources are used primarily to support and provide adequate service to the coffee growers by facilitating and financing the production, harvesting, processing, transport and exporting of coffee. These resources are also used to partially shield farmers against external shocks through an internal price system. In this system, the NFCG sets an internal price paid to farmers as a function of international prices and guarantees the purchase of all coffee that meets quality requirements at this price. It partially reduces the volatility because farmers receive higher prices than they would otherwise receive during bust periods, and lower prices during booms. The internal price paid to coffee-growers is the same across all regions and net of the coffee export tax, and transportation and other markup costs incurred by exporters. Figure 2 shows the dynamics of the internal and international coffee prices.

\subsection{Coffee Booms and Busts}

Between 1950 and 2000, the world coffee market witnessed a series of contractions and expansions. During this period, Brazilian frosts and droughts were a major source of fluctuations in the international price of coffee. Harsh frosts can kill entire coffee trees and affect the following harvests, and since new plants take 3-4 years before the trees begin to bear fruit, it can have short- and mid-terms consequences on the supply of coffee. Brazil is the only major producer vulnerable to frosts due to its unique geographic and climatic conditions. The most severe frost occurred in 1976, which hit 55 to 70 percent of the coffee crops and generated world shortages of the crop product (Caviedes, 1981).This coincided

with a rise in the international price of coffee of about 130 percent, the major boom in 
coffee prices in the recent history of the coffee market. In 1953 and 1994, other episodes of intense frosts destroyed crops and increased coffee prices by 15 to 70 percent relative to the previous year. Coffee prices also rose sharply between 1985 and 1986 because of a severe drought that decimated Brazilian coffee crops. While this shock was less severe compared to the 1976 frost, it coincided with a 94-percent increase in coffee prices in 1986.

Besides the frosts and droughts, there were other factors that also affected coffee prices. The coffee shortage caused by the 1985 drought was completely reversed by the supply expansion following the collapse of the International World Coffee Organization in 1989 (which regulated world coffee prices through a quota system). ${ }^{13}$ In the years following the collapse, coffee prices fell to historically low levels. While prices rose in 1994 because of the Brazilian frost, they fell abruptly to new unprecedented levels from 1998 to 2002 due to a rapid and sharp expansion in the supply of coffee from Brazil and Vietnam. The rapid expansion in Brazilian coffee production was caused by a government policy which promoted massive planting in areas affected by the 1994 frost and a series of reforms that devalued exchange rates and boosted exports (Akiyama et al., 2001). At the same time, Vietnam's coffee industry was rapidly expanding during that years as result of the restoration of bilateral trade relations with the United States, and aggressive government export policies (Nguyen and Grote, 2004). Consequently, Vietnam had become the world's leading producer of Robusta beans by the late 1990s, second only to Brazil in total coffee production.

Figure 2 documents in detail the timing of these events. In sum, the major coffee booms and busts originated outside of Colombia and are therefore plausibly exogenous to individual schooling decisions. As a result of these shocks, different cohorts faced different world coffee prices, thus different returns to coffee-related work, during their school-going years. As we shall see, this translated into differences in completed schooling across areas with varying coffee cultivation patterns.

\section{Data}

\subsection{Coffee Cultivation and Price Data}

This paper uses data on average annual world coffee prices from the National Federation of Coffee Growers. Using Colombian consumer price index and exchange rate data, I convert the coffee price series to real 1998 Colombian pesos. Because the consumer price index is available only from 1954 onwards, my analysis focuses on the years 1954-2003. As discussed

\footnotetext{
${ }^{13}$ The organization included both exporting and importing countries. In 1989, consumers in member countries were demanding increased quality of coffee and the end of selling coffee to non-member importing countries at reduced prices. The disagreement on a way to control exports to non-member countries, combined with Brazil's lack of interest, led to the suspension of the export quota system (Akiyama et al., 2001).
} 
above, this period includes the major boom and bust episodes in the recent history of the coffee market. Although individual human capital investments are unlikely to affect the internal price paid to a coffee grower, I use international coffee prices in the main analysis. Supplementary analyses instrument the international price of coffee with data on Brazilian coffee production, available from the Brazilian Institute for Applied Economic Research (IPEA).

To measure local coffee intensity, I draw on data from the NFCG's 1932 coffee census, the first nation-wide enumeration of coffee growers conducted in Colombia. Using these data, the coffee intensity of municipality $j$ is measured as the total hectares of land used for cultivating coffee in that municipality in 1932. I scale this variable by the total land area, given that some municipalities in Colombia vary in size. ${ }^{14}$ Since coffee cultivation intensity is measured before the major coffee price shocks, endogenous production responses to variation in coffee prices is not a concern. Still, this measure is likely to accurately capture the relative importance of the coffee to the local economy during the entire period of analysis. As discussed above, climatic and geographic differences within Colombia largely determine the suitability and thus distribution of coffee cultivation (de Graaff, 1986). This is reflected in a high persistence of the geographic distribution of coffee cultivation patterns over time. As an illustration, Figure 3 plots the 1970 and 1932 coffee cultivation intensity ranks. It shows that municipalities with relatively high coffee cultivation intensities in 1932 tend to be the same ones with relatively high coffee cultivation intensities in 1970, with a correlation coefficient of roughly 0.87 . The estimated slope of this relationship is 0.90: a 10 percentile increase in 1932 coffee cultivation intensity is associated with a 9 percentile increase in 1970 coffee cultivation intensity. The conclusions are essentially the same if coffee cultivation intensity is measured using the 1970 census (see Appendix ??).

There is substantial variation in the intensity of coffee cultivation across municipalities. For example, about 45 percent of municipalities in the sample are not classified as coffee producers. Conditional on being coffee producing, the standard deviation in coffee cultivation is 4.56 hectares per each 100 hectares of total municipality area (relative to a mean of 2.8). This variation in the role of coffee to the local economy, combined with the timing of coffee price shocks, forms the basis of my identification strategy.

\subsection{Census Data and Definitions}

My long-run analysis relies on data from the 1973, 1993 and 2005 Colombian censuses, available through the Integrated Public Use Micro Sample (IPUMS). ${ }^{15}$ Another available

\footnotetext{
${ }^{14}$ Appendix Table ?? shows that the results are qualitatively and quantitively similar if I use coffee cultivation in levels rather than normalized by total land area.

${ }^{15}$ The IPUMS data are publicly available at https://international.ipums.org/international/.
} 
census is that of 1985. I do not use this census in my long-run analysis because it does not contain any information about an individual's place of birth, information that is important to identify exposure to coffee market conditions in childhood (as described in detail below). The IPUMS provides information on 10 percent of individuals randomly drawn from the original census, along with frequency weights to preserve national representation. It includes basic demographic and socioeconomic information, including education, age, municipalityof-birth, and labor force participation, as well as industry and status in employment (class of worker) for individuals employed at the time of the census. I limit the sample to cohorts born between 1949 and 1983, who are 22-56 years old at the time they are observed in the census and thus have likely completed their schooling decisions. ${ }^{16}$

To estimate the extent to which individuals were exposed to coffee market conditions when they were of school-going age, I assume that the municipality where they were born is the same as the one where they grew up. ${ }^{17}$ The data suggest that this assignment is plausible. Approximately 75 percent of children aged 5-16 were residing in their place of birth at the time of the 1964, 1973, 1985 and 1993 censuses. ${ }^{18}$ Moreover, the vast majority of children residing in their place of birth did not move to a different municipality in the previous five years (about 96 percent), suggesting that migration was infrequent. ${ }^{19}$ Since children aged 5-16 in these censuses are virtually the same ones in the long-run analysis when they are adults, these statistics are very informative that the assignment is likely to be highly accurate for most of the sample. ${ }^{20}$ Among the remaining 25 percent who reside in a different municipality at census time, about 50 percent lived in their place of birth five years earlier and this is true even among older children (ages 11-16). This suggests that

\footnotetext{
${ }^{16}$ Specifically, the 1973 census includes cohorts born between 1949 and 1951, or individuals who are 22-24 years of age; the 1993 census includes cohorts born between 1949 and 1971, or individuals aged 22-44; and the 2005 census includes cohorts born between 1949 and 1983, or individuals aged 22-56.

${ }^{17}$ In Colombia, children must start school the year they turn 6 . Since I use age at census time to infer individuals' year of birth, I am not able to identify the exact year they turned 6 . Consequently, I assume that the school-age period begins when an individual is $t+5$ years old, where $t=$ census - age at census. The results are essentially the same if I use instead $t+6$.

${ }^{18}$ The census enumerators asked respondents whether "the actual municipality of residence is the same as the one where they were born." This information allows to directly identify "movers." The 1964 and 1985 censuses did not ask the birth municipality for those individuals whose current municipality of residence is different from their municipality of birth. In this case, it is even possible to identify "movers", but not their place of birth.

${ }^{19}$ These migration patterns are not exclusive to Colombia. These patterns are similar to that observed in other Latin American countries such as Bolivia, Brazil, Chile, and Mexico (see, for example, case-count view of the "place of residence 5 years ago" variable for these countries at https://international.ipums . org/international-action/variables/MIGRATE5\#description_section, last accessed on February 18, 2019). Other studies have also used the place of birth to identify childhood exposure effects in other settings, including Duflo (2001) for Indonesia, and Bleakley (2010) for the United States, Mexico, and Brazil.

${ }^{20}$ For example, I observe the 1978 cohort at ages 7 and 15 in the 1985 and 1993 censuses, but this cohort enters into the long-run analysis only through the 2005 census sample.
} 
the municipality of birth will still contain some information about childhood coffee market conditions for this group.

I match the individual census data with municipality-level coffee cultivation and price data by using information on the municipality and year of birth. ${ }^{21}$ Childhood exposure is calculated as the interaction between the average world coffee prices observed during cohorts' school-going years (ages 5-16) and the time-invariant measure of coffee cultivation intensity in the municipality of birth. As shown above, coffee cultivation patterns are highly persistent over time, so the pre-determined measure of coffee cultivation intensity is likely to be a good approximation of "real" baseline market size and accurately capture differences in childhood exposure across areas.

The primary outcome of interest is total years of education attained as defined in the census. In the original data, this variable was top coded by applying a cap at 18 years in the 1973 and 2005 census data and at 12 years in the 1993 census. Despite these differences, the results are very similar when excluding the 1993 census or when I impose a uniform top-coding. I also estimate the effects of coffee price shocks on adult income. Since the Colombian census does not collect any information about income, I follow Bleakley (2010) and assign income scores based on the average earnings of individuals in the same industry, class of worker and gender cell, drawn from other Latin American censuses with available information on income. ${ }^{22}$ The resulting indicator represents (log) average earnings across industry/class-of-worker/gender cells (after removing census-country specific effects), or simply log earnings. I describe in more detail this income score in Online Appendix ??.

The baseline sample consists of approximately 2.7 million observations. ${ }^{23}$ Since the key identifying variation relies on changes across birth cohorts and municipalities, I aggregate the data into cell means by birth cohort, municipality of birth, census-year, and gender to ease the computational burden. ${ }^{24}$ The resulting means are used as dependent variables in the regressions below, which are weighted by square root of the cell size to adjust for precision with which the cell means are estimated. The results are identical if the regressions are estimated using individual-level data. Descriptive statistics of these data are shown in Panel A of Table 1.

\footnotetext{
${ }^{21}$ The number of municipalities in Colombia is about 1120 . However, the IPUMS combines neighboring municipalities to create geographical units with population greater than 20000, yielding approximately 500 time-consistent geographical units or simply municipalities. Therefore, I aggregate the coffee census data into this broader definition of municipality.

${ }^{22}$ The 1973 Colombian census does provide information on total income, but it covers a too limited set of cohorts in my analysis.

${ }^{23}$ The expanded sample with census weights consist of about 33 million observations. These weights are employed in all analyses. The results remain virtually the same if the census weights are not used.

${ }^{24}$ In generating these aggregate data, I first expand the sample using the frequency weights given by the census IPUMS.
} 


\subsection{Other Data}

Other data sources are also used for supplementary analyses. To examine the relationship between coffee price shocks and school enrollment, I use published statistics about education from the Colombian Anuario General de Estadistica for the period 1954-1977. ${ }^{25}$ It reports the total number of students enrolled in public and private schools at the department level. ${ }^{26}$ Breakdowns of these data at finer geographical levels are not available. Moreover, information on secondary-school enrollment is not systematically reported in these books, so I can examine only changes in primary-school enrollment. Because these records also contain information on the number of teachers, I can also explore the potential role of teacher supply responses to coffee market conditions. Primary-school enrollment and teacher rates are calculated using data on student enrollment and teachers in the numerator. For the denominator, I linearly extrapolate population aged 5-11 using census data.

Finally, I have obtained data on a number of time-invariant municipality characteristics. These include local violence, incidence of specific diseases, manufacturing employment, level of development, and transport infrastructure, all of which are measured around 1950. I control for differential trends associated with these characteristics to assess the robustness of the main results. I also use data on conflict intensity from Dube and Vargas (2013) to examine the potential role of violence in explaining the main results. Appendix Table ?? describes in more detail the source and definition of these variables.

\section{Empirical Strategy}

To examine the long-run impacts of coffee price shocks, I compare cohorts based on the intensity of coffee cultivation in their place of birth, and the world coffee prices during their school-going years. Figure 4 illustrates the basic idea behind this approach. It plots the average coffee price faced by cohorts in childhood and the difference in years of schooling between individuals born in high and low cultivation intensity municipalities. For simplicity and illustration, high and low coffee cultivation areas are defined as those municipalities above and below the 75 th percentile of the coffee cultivation distribution, respectively. ${ }^{27}$ The figure clearly shows that coffee booms in childhood are associated with fewer years of completed schooling for individuals in high cultivation areas than for those in low cultivation areas. The pattern is completely reversed when childhood coffee prices fall.

This idea can be generalized to a regression framework that exploits greater variation

\footnotetext{
${ }^{25}$ After 1977, education statistics were not systematically collected and reported in these books.

${ }^{26}$ There are 33 departments in Colombia. However, in the education statistics, some departments are combined with neighboring departments, leading to a total of 22 geographical units or simply departments.

${ }^{27}$ The patterns are very similar if I instead use the median coffee cultivation to define high and low cultivation areas.
} 
across areas and cohorts. Before formalizing this approach, I first present a short-run specification that is analogous to the one used in previous literature examining the impact of income shocks on contemporaneous schooling outcomes.

Short-run Effects. Previous literature has so far focused on the short-run effects of local income shocks on human capital formation. Following this literature, an analogous short-run specification of the effects of coffee price shocks would be as follows:

$$
Y_{\text {jagt }}=\alpha+\beta\left(\mathbb{P}_{t} \times \mathbb{I}_{j}\right)+\kappa \mathbf{T}_{j t}+\lambda_{j}+\gamma_{g}+\mu_{a t}+\xi_{j a g t}
$$

where $Y$ is either the proportion of children who are currently attending school or working in area $j$, cohort aged $a$ and gender $g$ at the time of the year $t$ census. The key independent variable is given by the interaction between (log) real world coffee prices, $\mathbb{P}_{t}$, and the (timeinvariant) measure of coffee cultivation intensity, $\mathbb{I}_{j}$. This interaction term measures the prevailing coffee market conditions at the census-year $t$. The specification includes controls for area fixed effects $\left(\lambda_{j}\right)$, and cohort-census fixed effects $\left(\mu_{a t}\right)$, which capture any timeinvariant differences across areas and common changes over time. The area-specific time trends, $\mathbf{T}_{j t}$, account for possible long-run dynamics in socioeconomic and other characteristics across areas.

This model is basically a differences-in-differences (DID) setup that uses two continuous measures of "treatment" intensities, thereby exploiting exploit greater variation in the data than the standard two-group/two-period DID. In Section 5.1, I present results from estimating this model. In doing so, I use data from the 1973, 1985 and 1993 census data. ${ }^{28}$ Unlike the long-run analysis described below, I consider the department rather than municipality as unit of analysis for two reasons. First, information on the municipality of birth was not collected in 1985. Second, matching individuals with coffee cultivation data of the municipality where they are observed at the time of census is problematic because of selective migration. Since the vast majority of migration occurs within departments, aggregating the data to the department level largely reduces concerns about selective migration. ${ }^{29}$

Long-run Effects. The model above, however, does not allow to infer the extent to which local income shocks induced by changes in coffee prices have long-run effects on human capital. To examine this question, I adopt an intention-to-treat (ITT) design that compares long-run outcomes of cohorts with varying coffee cultivation intensities in their municipality of birth, and different world coffee prices during their school-going years. In

\footnotetext{
${ }^{28}$ To improve precision, I limit the sample to children in rural areas, since coffee price shocks is likely to have only limited impacts in large urban areas. While including children in urban areas leads to reduced precision, the results and conclusions are basically the same.

${ }^{29}$ Indeed, only 5 percent of children moved to a municipality in a different department in the previous five years before the census year. Appendix Table ?? documents that the long-run results are similar if the data are aggregated at the department (rather than municipality) level.
} 
particular, I employ the following specification:

$$
Y_{j g c t}=\tilde{\alpha}+\tilde{\beta}\left(\overline{\mathbb{P}}_{t} \times \mathbb{I}_{j}\right)+\tilde{\kappa} \mathbf{T}_{j t}+\tilde{\lambda}_{j}+\tilde{\gamma}_{g}+\tilde{\mu}_{c t}+\tilde{\xi}_{j g c t}
$$

where $Y$ is average years of completed schooling or log earnings for individuals in municipality $j$, born in year $t$, gender $g$, and observed in census-year $c$. Now, the key independent variable is given by the interaction of childhood coffee prices, $\overline{\mathbb{P}}_{t}$, and the (time-invariant) measure of coffee cultivation intensity in the municipality of birth, $\mathbb{I}_{j} .{ }^{30}$ Childhood coffee prices is measured as the (log) average coffee prices observed between the years $t+5$ and $t+16$. In all specifications, I include municipality fixed effects $\left(\tilde{\lambda}_{j}\right)$, birth cohort $\times$ census-year fixed effects $\left(\tilde{\mu}_{c t}\right)$, and municipality-specific time trends $\left(\mathbf{T}_{j t}\right)$. The results from estimating equation (2) are presented in Section 5.2.

This specification is an extended version of the model (1) that allows to analyze long-run effects. The key parameter of interest is $\tilde{\beta}$, which summarizes the magnitude of the longterm impacts of coffee price shocks. Identification requires the counterfactual assumption that absent any change in coffee prices, long-run outcomes of individuals in municipalities that produce coffee more and less intensively would have followed the same trends. This identifying assumption is plausible insofar both global coffee prices and geography of coffee cultivation are not affected by changes in an area's human capital investments. Although municipalities with varying coffee cultivation intensities may differ in ways that could affect human capital investments, any unobserved differences that are time-invariant will be stripped out by the inclusion of municipality fixed effects. Identification would be threatened only if there were omitted determinants of long-run individual human capital varying both over time in the same way as international coffee prices and disproportionally over space across municipalities cultivating more coffee. In principle, it is hard to think of any such a story given that many of the factors known to influence world coffee prices during the period analysis originated outside of Colombia, and the timing of such shocks was plausibly unanticipated. Moreover, since the potential coffee market of an individual is given by her or his municipality of birth, it is not endogenous to future erratic changes in coffee price shocks.

Since treatment intensity varies across areas and cohorts, this fuzzy differences-in-

\footnotetext{
${ }^{30} \mathrm{As}$ mentioned above, the intensity of coffee cultivation is measured as the total of land used for cultivating coffee (scaled by municipality area) in 1932. An alternative approach would be to use coffee cultivation intensity in 1970 as the key treatment variable and generate an instrumental variable using data on coffee cultivation in 1932. The key independent variable would be constructed using a more recent measure of coffee cultivation intensity, and the instrumentation strategy would eliminate any possible bias induced by endogenous production responses to past coffee prices. The results are quantitively and qualitatively similar when following this approach. Hence, one can interpret equation (2) as a reduced-form expression, which is my focus for simplicity.
} 
differences estimates a weighted average of Wald-DIDs (De Chaisemartin and D'HaultfCEuille, 2017). ${ }^{31}$ In addition to the common trend assumption discussed above, identification in my setting also requires the absence of heterogenous effects over time. Results in Section 5.2 suggest that this seems to be the case (i.e., there is no evidence that the effects of coffee price shocks are heterogeneous across birth cohorts). ${ }^{32}$

After showing the baseline results, I also present results from a more flexible specification that allows to examine how the long-rung effects of coffee price shocks vary with children's exposure age:

$$
Y_{j g c t}=\tilde{\alpha}+\sum \tilde{\beta}^{a}\left(\overline{\mathbb{P}}_{t}^{a} \times \mathbb{I}_{j}\right)+\tilde{\kappa} \mathbf{T}_{j t}+\tilde{\lambda}_{j}+\tilde{\gamma}_{g}+\tilde{\mu}_{c t}+\tilde{\xi}_{j g c t}
$$

where $\mathbb{P}_{t}^{a}$ denotes now the (log) average coffee price observed at age $a$ for cohort $t$. I group exposure ages into four-year age bins to increase precision with which $\beta^{a}$ is estimated. This specification provides a more detailed picture of the relationship between coffee prices and completed schooling. It also provides an opportunity to directly evaluate the plausibility of the identifying assumption. If the research design is valid, then the magnitude of the coefficients should decline to zero for ages for which individuals already completed schooling decisions. Large and significant effects would suggest the presence of pre-existing differential trends in outcomes driven by other factors.

Throughout the analysis, I use standard errors that are clustered at the municipality level (or department level when using equation (1)) to account for potential serial correlation. A possible disadvantage of these standard errors is that they do not account for possible correlation across space, which might lead to misleading inference if there is significant spatial correlation in coffee suitability across municipalities. Appendix Table ?? shows that statistical significance is largely unaffected under different assumptions about the covariance-variance matrix that address spatial correlation in error terms.

The preferred specification includes a robust set of fixed effects and municipality-specific linear time trends, but results are almost unaffected if a number of additional controls are included (see Appendix ??). After presenting the basic long-run results below, I present further results that provide support to the main interpretation of the findings and assess some possible alternative explanations.

\footnotetext{
${ }^{31}$ I also consider binary definitions of the treatment by classifying areas into high and low cultivation intensities groups as well as periods into low and high coffee price categories. The conclusions are the same under these alternative definitions (see Appendix Table ??).

${ }^{32}$ I also estimate the time-corrected Wald ratio (Wald-TC) estimator proposed by De Chaisemartin and D'Haultf(Euille (2017), which does not rely on any assumption on treatment effects. I find point estimates that are extremely similar to the baseline, although the Wald-TC results are somewhat imprecise.
} 


\section{Results}

\subsection{Short-Run Effects on Schooling and Child Labor}

Before showing the long-run estimates, the focus of this paper, I examine the effect of coffee price shocks on contemporaneous school attendance and child labor as in previous studies. Table 2 shows the results from estimating model (1). For inference, I estimate standard errors clustered at the department level. Because these standard errors may be biased due to the small number of clusters (33 departments), I also calculate two-tailed $p$-values using the wild cluster bootstrap- $T$ method (Cameron et al., 2008). Column (1) documents that increases in real coffee prices are associated with reduced school attendance. The estimated coefficient is precisely estimated and thus highly significant at the conventional levels of significance. It implies that for the coffee price change from 1985 to 1993 (a reduction of $0.82 \log$ points), the increase in school attendance is about 2.3 percentage points larger in areas with one standard deviation larger amount of coffee cultivation $(-0.011 \times 0.82 \times$ $2.6=-0.023)$.

In columns (2)-(3), I estimate the model separately for children aged 5-11 and 12-16. The estimates suggest that both young and old children are negatively affected by increases in the real price of coffee, with magnitudes and significance that are extremely similar. One potential reason for this is that, as discussed above, the most labor-intensive activity in coffee farming is relatively simple and can be performed both for young and old children. This reasoning is consistent with previous reports documenting similar employment rates in the coffee sector among children aged 5-11 and 12-16 (Bernal and Cárdenas, 2006). Hence, changes in coffee prices can plausibly affect the opportunity cost of schooling both for young and old children.

I supplement these results by examining school enrollment rates using official statistics about education at the department-by-year level over the 1954-1977 period. An important strength of these data is that they are from administrative records and likely less subject to measurement error than self-reported school attendance. Column (4) shows the results from estimating a variant of equation (1) that uses a department-level panel of school enrollment rates. Consistent with the census results, I find that increases in international coffee prices are associated with reduced school enrollment rates, a relationship that is statistically significant at the conventional levels of significance. The sharp rise in the price of coffee from 1970 to 1976 (a difference of 0.78 log points) implied a reduction in school enrollment that is approximately 10 percentage points larger in municipalities with one standard deviation additional coffee cultivation. Since the average school enrollment rate in the sample is 72 percentage points, this is a relatively large effect. 
Column (5) shows the results of the effect of coffee price shocks on child labor. I find a positive effect of international coffee prices on this outcome, with an estimate coefficient of 0.003 (standard error $=0.0012$ ) which is statistically distinguishable from zero at the conventional levels of significance. The estimate implies that the fall in the price of coffee between 1985 and 1993 led to a decline in the proportion of child employment that is 0.7 percentage

points larger in municipalities with one standard deviation more coffee cultivation. This effect represents a 13-percent reduction relative to the sample mean.

Summarizing, the results of this section suggest that coffee booms lead to reduced school attendance and increased child labor. This finding is consistent with the view that during coffee booms, the opportunity cost of schooling rises significantly and consequently some youths at the margin respond by supplying more labor and reducing educational investments.

\subsection{Long-Run Effects on Completed Schooling}

\subsection{A Main Findings}

I now turn to the main question of whether income shocks induced by changes in coffee prices have long-term effects on completed human capital. I begin by examining graphically the relationship between these variables. In doing so, I estimate a semi-parametric and simpler version of equation (2) where the intensity of coffee cultivation is interacted with birth cohort dummies, adjusting for birth cohort $\times$ census-year fixed effects and municipality of birth fixed effects. The coefficients on these interactions compare the trends in schooling over time in municipalities with different coffee cultivation intensities. Figure 5 plots the coefficients and respective 95 percent confidence intervals. There are no differential trends in schooling among cohorts who were born between 1949 and 1955 across municipalities cultivating coffee more and less intensively. Given these cohorts were exposed to relatively stable and similar coffee prices in childhood, this lack of association provides reassuring evidence that there were no pre-existing differential trends in schooling across municipalities with varying coffee cultivation intensities. For the boom cohorts, those born between 1956 and 1977, there is a statistically significant decline in schooling in municipalities cultivating disproportionally more coffee. The pattern is reversed for the cohorts born between 1978 and 1983, who faced lower coffee prices in childhood compared to the boom cohorts. Overall, these patterns in schooling mirror the trends in childhood coffee prices.

Table 3 reports formal estimates of the effect of coffee price shocks on educational attainment based on equation (2). Column (1) presents results from a specification with no covariates besides municipality, cohort, census-year and gender fixed effects. Confirming the visual evidence, I find a significant effect of coffee price shocks on schooling, with a 
coefficient of -0.047 (standard error $=0.013$ ). It implies that higher coffee prices during school-going years lead to fewer years of completed schooling in areas with greater intensity of coffee cultivation. Columns (2)-(4) add other controls sequentially to this specification. The addition of municipality-specific linear time trends in column (2) has small effects on the estimated coefficient, which is now -0.040 (standard error $=0.009$ ). Point estimate is similarly little affected when census-year $\times$ cohort fixed effects are included (column 3). In addition, controlling for municipality $\times$ census-year fixed effects in column (4) hardly change the results (-0.04 versus -0.038$)$.

Column (5) drops observations from the 1993 census to determine the extent to differences in the coding of schooling years across censuses affect the results. While this sample restriction drops 35 percent of observations in the expanded sample, the magnitude and standard error of the estimated relationship remain unchanged. Finally, column (6) imposes a uniform top-coding by applying a cap at 12 years across all census data. While this reduces somewhat the coefficient, it remains quite precise and highly significant. Overall, neither set of alternative estimates are statistically distinguishable from my preferred baseline specification (column 3).

To explore how the effects of coffee price shocks vary with children's exposure age, Figure 6 shows the results from estimating the extended model (3). It plots estimates of $\beta^{a}$ and respective 95 percent confidence intervals. Consistent with the identifying assumption, the effects of exposure to coffee price shocks after age 16 are small and statistically indistinguishable from zero. This is unsurprising given that the vast majority of individuals completed about 12 years of schooling (about 90 percent) and thus finalized schooling decisions at age 17. The largest negative and significant effects are observed for exposure at ages ranging from 5 to 16, the timing of schooling decisions. The effects of exposure to coffee prices before age 5 are smaller and generally statistically insignificant. ${ }^{33}$ The timing of the effects is in line with the baseline specification and consistent with the interpretation that coffee price shocks induce an opportunity cost of schooling effect that dominates any income effect.

Earlier cohorts were overall less educated than later cohorts, so dropping out of school may mean something different over time. This suggests that there may be some degree of heterogeneity of the estimated effects across birth cohorts. To investigate this possibility, I divide the cohorts into three equal-sized groups and create dummy indicators for each group.

${ }^{33}$ The fetal origins literature suggests that income shocks during the prenatal period should have longrun repercussions on schooling (see Almond and Currie (2011) for a review of this literature). However, since income shocks are accompanied by substitution and income effects in the production function of infant health (Miller and Urdinola, 2010), one possibility is that both effects are of similar magnitude in terms of long-run outcomes in this setting. 
The model (2) is then reestimated, but adding interactions between the key independent variable and these dummy indicators (see Appendix Table ??, column 2). These additional interactions are statistically indistinguishable from zero. Hence, there is little evidence of heterogeneous effects across birth cohorts.

The baseline specification assumes that the effects of increases and decreases in the real price of coffee are symmetric. While Figures 4 and 5 suggest that this appears to be the case, I test more formally for asymmetric effects. In doing so, I rerun the baseline model (2), but adding an interaction between the main independent variable and a dummy indicating if the birth cohort $t$ is facing an increase in childhood coffee prices relative to the birth cohort $t-1 .^{34}$ The coefficient on this additional interaction term is statistically insignificant and very small in magnitude (see Appendix Table ??, column 3). Therefore, there is no evidence of asymmetric effects.

Overall, the results indicate that coffee booms during school-going years lead to reduced educational attainment. This suggest that income shocks induced by changes in the real price of coffee have persistent effects on completed human capital. To interpret the results, consider the change in the average price of the coffee from cohorts born in 1954 to those born in 1970. The former cohort was exposed to relatively low coffee prices when they were of school-going age, while the latter faced the major booms caused by the Brazilian frosts and droughts. This resulted in a difference of $0.5 \mathrm{log}$ points in the average coffee price these cohorts faced when they were of normal schooling ages. The preferred estimated coefficient of -0.040 implies that, given the 50 percent change in the international price of coffee, the decline in education is 0.09 years larger in areas with one standard deviation more coffee cultivation $(0.5 \times-0.04 \times 4.5=-0.09)$.

\subsection{B Brazilian Coffee Production as a Source of Variation}

A potential concern is that Colombia is a major coffee exporting nation and it may bias the estimates above. In particular, it might be that education changes simply reflect unobservable shocks that negatively affect both human capital investments and coffee production levels in large coffee production regions - which in turn causes the international prices to increase. I argue that this is unlikely to be the case given that the major booms and busts in the period of analysis originated outside of Colombia. In this section, I provide explicit evidence supporting this claim by exploiting variation in coffee production volume of Brazil. Brazil is a world's leading producer of coffee, and the major booms and busts in the study period were the result of changes in its supply. Consequently, variations in Brazilian coffee production levels provide a shock to international coffee prices virtually independent of

\footnotetext{
${ }^{34}$ The conclusions are unchanged if I instead use a dummy indicating whether childhood coffee prices of cohort $t$ is higher relative to the mean childhood coffee prices.
} 
Colombian coffee market conditions. ${ }^{35}$

I begin by presenting reduced-form estimates of the relationship between Brazilian coffee production levels and educational attainment. Specifically, I rerun the baseline specification (2), but replace coffee prices by Brazilian coffee production. These results are shown in column (2) of Table 4. I find that reductions in Brazilian coffee production levels are associated with fewer years of education, a relationship that is statistically distinguishable from zero at the conventional levels of significance. This finding makes sense and is in line with the baseline results given that large contractions in coffee production in Brazil translate into increased coffee prices.

Next, I present results from estimating two-stage least squares (2SLS) regressions where Brazilian coffee production levels is used as a source of exogenous variation in the international price of coffee. Specifically, I use the interaction between coffee cultivation intensity and Brazilian coffee production as an instrument for the interaction between coffee prices and coffee cultivation intensity. This means that the model will be identified solely by the variation induced by coffee production shocks in Brazil, but the magnitudes can be interpreted as the effect of changes in coffee prices. Given the high correlation between coffee prices and Brazilian coffee supply, the first stage is very strong with a coefficient of around -1.3 (column 3). ${ }^{36}$ The magnitude and significance of the 2SLS results are extremely similar to the baseline (column 4). Hence, it seems unlikely that my baseline results reflect unobservable shocks affecting both individual human capital investments and international coffee price dynamics.

\subsection{Gender Heterogeneities}

Although women's labor supply was rapidly increasing during the 1970s and 1980s, it was generally much lower compared to that of men, with differences in employment rates of more than 40 percentage points. These differences are similarly striking when considering only children under 16 years of age: while 18 percent of boys were employed in 1985, this figure was only 9 percent for girls. And these gender differences in employment rates are similarly found in the coffee sector (Bernal and Cárdenas, 2006). This suggests that many of the factors affecting the decision of supplying labor in general and in the coffee sector were relatively less important for girls than for boys. If this is the case, one would expect girls to be less responsive to changes in the same coffee-related work opportunities, and hence female school attainment would decline less than male. Confirming this prediction

\footnotetext{
${ }^{35}$ The correlation between international coffee prices and Brazilian coffee production is about -0.60 .

${ }^{36} \mathrm{An}$ alternative instrumentation strategy would be to use the interaction between childhood Brazilian supply and coffee cultivation levels in 1932 as an instrumental variable for the interaction between childhood coffee prices and coffee cultivation levels in 1970. The conclusions are essentially the same when I implement this alternative strategy.
} 
represents a test that coffee price shocks affect schooling primarily through changes in the opportunity cost of schooling.

In Table 5, columns (1)-(2) show estimates of the effect of coffee price shocks on child labor separately for female and males using the model (1). I find that coffee booms lead to an increase in child labor rates that is significantly larger for boys than for girls. I find a similar pattern when I examine the long-run effects of coffee price shocks on schooling (columns 3-4). Indeed, the effects on schooling are significantly larger and more precisely estimated for males than for females.

The correspondence in these patterns across gender is remarkable and consistent with the interpretation that the long-run impacts are largely driven by changes in the opportunity cost of schooling. Boys respond more to changes in the return to coffee-related work, and it translates into larger changes in their completed human capital relative to girls. Any alternative mechanism would have to vary in a similar gender-specific manner. This suggests that factors that only affect general human capital, such as changes in the supply or quality of schools, are less likely to play a role.

\subsection{Interpretation of Magnitude}

To gauge the magnitude of the results, I perform a simple exercise that measures what would have been the level of completed schooling of individuals born in 1970 (boom cohort) if they had been exposed to the same childhood coffee prices as those born in 1954 (pre-boom cohort) - a difference of about 50 percent in childhood coffee prices. I can use the baseline result reported in column (3) of Table 3 to compute the counterfactual level of schooling of the boom cohort for each municipality. This is equal to the observed level of schooling of the boom cohort minus the estimated parameter of $\tilde{\beta}$ multiplied by the intensity of coffee cultivation and the change in (log) childhood coffee prices: years of education ${ }_{\text {jgc,1970 }}$

$-\hat{\tilde{\beta}} \times \mathbb{I}_{j} \times 0.5$. These counterfactuals are then averaged across all municipalities to obtain an overall counterfactual measure of completed human capital. The calculations suggest that, on average, the 1970 cohort would have completed an additional 0.035 years of schooling without the shock.

This estimate represents an ITT effect because exposure to coffee market conditions is based on an individual's place of birth (rather than the childhood municipality of residence). Using information on geographical mobility rates, I can calculate an approximate estimate of the treatment-on-the-treated (TOT) effect by dividing the ITT impact by the fraction 
of school-age children residing in their place of birth at census time. ${ }^{37}$ As discussed in Section 3.2, about 75 percent of individuals were residing in their place of birth when they were of school-going age. This suggests a TOT effect of 0.045 years of schooling $(0.045=0.035 / 0.75)$.

To place the magnitude of this effect in perspective, I can compare it with well-documented interventions targeting education in developing countries. Perhaps, the Sekolah Dasar INPRES program in Indonesia and the Colombian PACES program are two of the best-known and well-documented examples of such interventions. The INPRES program resulted in the construction of more than 60,000 new primary-schools within a short timeframe, increasing enrollment rates from 69 to 83 percent (Duflo, 2001). In the PACES program, which is particularly relevant to my setting given its focus on Colombia, students were randomized to receive private school vouchers that reduced school fees by about 80 percent (Angrist et al., 2002). The INPRES program raised educational attainment by 0.12 years in high intensity program regions, while children treated in the PACES program completed an additional 0.1 years of schooling. Scaling these effects by a 50 percent variation in treatment intensity, the INPRES program had an impact of 0.10 years on educational attainment, and the PACES program had an effect of 0.06 years of education. ${ }^{38}$ Therefore, the magnitude of my results is quite similar to that of the PACES program, and approximately one half the effect of the INPRES program.

\subsection{Robustness Checks}

I have conducted a number of specification checks to investigate the robustness of the main findings, all of which are described in detail in the Online Appendix. Appendix ?? documents that the conclusions remain essentially unchanged under different alternative strategies to capture with greater precision exposure to coffee market conditions (excluding "movers" or aggregating the data to the department level). Appendix ?? documents the robustness of the results to a variety of alternative specifications: excluding non-growing areas, measuring coffee cultivation intensity using the 1970 coffee census, and controlling

\footnotetext{
${ }^{37}$ This is a "back-of-the-envelope" calculation of the TOT effect. Ideally, if one had information on an individual's place of residence in childhood, one could instead estimate the TOT effect using a 2SLS regression. Under this approach, the first stage would be the specification (2), but using childhood coffee market conditions (based on an individual's childhood municipality of residence) as dependent variable. The coefficient on this first stage would be approximately equal to the fraction of school-age children residing in their place of birth. To extent to which information on geographical mobility rates is accurate, the "back-of-the-envelope" estimate would tend to be similar to that produced by this 2SLS approach.

${ }^{38}$ Duflo (2001) estimates the baseline effects of the INPRES program by comparing high and low intensity regions (see the coefficient reported in column (1) of Table 4). The difference in treatment intensities between low and high intensity regions is about 60 percent, so I can normalize the baseline estimate by multiplying the baseline coefficient by 0.5/0.6. Given that the PACES program reduced on average school fees by 80 percent, I normalize the treatment effect by multiplying the baseline estimate of 0.1 by $0.5 / 0.80$.
} 
for interactions of time fixed effects with a number of baseline characteristics. In Appendix ??, I investigate the role of selective attrition and conclude that it is not large enough to significantly affect the estimates. Appendix ?? considers alternative assumptions about the covariance-variance matrix (using the Conley's spatial covariance matrix, clustering errors either at the department level or both at the municipality and year-of-birth level) and shows that inference is largely unaffected by the choice between different assumptions. Finally, Appendix ?? conducts a non-parametric permutation test and documents that the conclusions remain unchanged.

\subsection{Alternative Explanations}

While I have argued that the opportunity cost of studying is an important mechanism linking childhood coffee price shocks to long-run human capital, there are other possible explanations for the results. These include supply of teachers, household work decisions, and local violence. This section discusses these hypotheses and provides tests about their relevance.

\subsection{A Supply of Teachers}

One might argue that increased return to coffee-related work may not only raise the opportunity cost of time for students, but also for teachers. Teachers may leave school during coffee boom years to participate in coffee-related production activities, including weeding and harvesting, which could negatively affect student outcomes. It may explain the negative relationship between coffee prices and educational attainment. I argue this is unlikely given that teachers are highly educated workers with salaries significantly large relative to wages in the agricultural sector in general. According to the 1973 census, the median wage in the educational sector is more than 300 percent higher than that in the agricultural sector. The differences are substantial even if one compares the median income in the educational sector with the 90th percentile income in the agricultural sector, a differential of the order of 98 percent.

Published data about teachers allow me to directly evaluate the teacher supply hypothesis. I estimate the contemporaneous effects of coffee price shocks on teacher rates. If changes in the supply of teachers play a role, then one would expect to see significant and negative effects of coffee prices on this variable. Table 6, column (1) shows no evidence that coffee price shocks have a meaningful effect on teacher rates, suggesting that this alternative history is unlikely to be the primary force behind the main findings.

One related issue is class size. If the number of teachers does not vary with coffee prices, the fact that some kids drop out means that whose who stay in school have smaller classrooms, thereby potentially affecting long-run outcomes in adulthood. Given the evidence 
that smaller classrooms have positive effects on human capital formation (Chetty et al., 2011b; Krueger, 1999), the extent to which higher coffee prices are associated with smaller classrooms, this would tend to lead to better long-run outcomes in areas with greater intensity of coffee cultivation. But this is the opposite to the observed differences in long-run outcomes I find. Hence, it is unlikely that my findings reflect changes in classrooms.

\subsection{B Household Work Decisions}

Coffee price shocks may increase the probability that adult family members enter the workforce. Hence, a possibility is that the patterns of schooling I find are not very determined by the opportunity cost of schooling but by adults making a child stay home (rather than in school) when they enter the workforce. This could explain $\beta<0$ in the estimation of equation (2). However, the results in Section 5.1 showing that children enter the labor force (and hence do not stay home) during coffee booms provide evidence against this alternative interpretation. Moreover, this alternative hypothesis seems harder to reconcile with the gender-specific effects documented in Section 5.2.C. For this to arise, adults would have to be more likely to make males stay home during booms than females. But it is unclear why this would be the case.

To investigate this potential mechanism in more detail, I examine directly the relationship between coffee price shocks and the fraction of household members over 16 who are employed at census time using the model (1). The results are shown in Table 6, column (2). If coffee price shocks affect schooling through changes in household work decisions, then one should observe a significant effect in this regression. I find no evidence that coffee price shocks change the probability that adults work, suggesting that the household work hypothesis is unlikely to be an important mechanism. ${ }^{39}$

\subsection{Local Violence}

Colombia faced an intense war between governments, paramilitary groups, and left-wing guerillas that began in the mid-1960s and affected some regions. A prominent body of work, conducted in a variety of countries, have documented that income shocks can affect the intensity of conflicts (Dube and Vargas, 2013; Angrist and Kugler, 2008). In turn, intense violence episodes may negatively affect school's physical and human resources, and hence have disruptive effects on human capital formation. To explain the reduction in educational attainment I find, increases in the price of coffee should significantly increase

\footnotetext{
${ }^{39}$ Note that this result does not mean that adult participation in the coffee sector is not affected by changes in coffee prices. When the returns to coffee-related work are relatively high, some adults may switch from one employment in a different sector to one in the coffee sector without necessarily altering overall employment rates. But this does not affect my conclusions that the household work hypothesis is unlikely to play a major role.
} 
violence disproportionately in municipalities cultivating more coffee. The evidence indicates that the exact opposite is true. Dube and Vargas (2013) convincingly show that increased coffee prices lead to less guerrilla attacks, less paramilitary attacks, and less clashes in areas where coffee cultivation is more salient. The extent to which changes in violence matter, this mechanism would imply positive effects of coffee price shocks on schooling, which is inconsistent with my results.

Using data on conflict, I can empirically assess the possibility that differences in violence intensity during coffee booms explain my results. In Appendix Table ??, I reestimate the long-run regression including interactions of coffee prices $\times$ coffee cultivation intensity with different measures of conflict intensity (attacks, clashes, massacres, and political kidnappings). If my results were entirely driven by differences in conflict intensity, one should observe significant estimates on these interactions and an insignificant coefficient on the log coffee price $\times$ coffee cultivation intensity interaction. None of the additional interactions is statistically significant. Moreover, the magnitude and standard error of the key coefficient of interest is very similar to the baseline. Hence, it is very unlikely that coffee price shocks act primarily through changes in conflict intensity.

\subsection{Long-Run Effects on Earnings}

\subsection{A Main Findings}

After establishing that coffee price shocks have a robust effect on completed education and the likely mechanism behind these patterns, I then examine potential changes in earnings in adulthood. Work at earlier ages may provide some benefits, including acquisition of specific skills, increased social capital and general work experience, that may be rewarded later in the labor market. If these potential rewards are large relative to income losses from reduced schooling, then this would imply positive overall impacts on subsequent labor market prospects.

To examine this question, I rerun the baseline model (2), but use the industry-based earnings score as dependent variable. The results are shown in Table 7. Column (1) shows the results from a specification that controls for a basic set of fixed effects (i.e., municipality, birth year, gender and census-year fixed effects). I find an estimate of $\tilde{\beta}$ of -0.0023 (standard error $=0.001$ ), which is statistically significant at the 5 percent level. This suggests that higher coffee prices in childhood are associate with lower adult earnings. Columns (2)-(3) document that the coefficient is slightly larger in magnitude and relatively more precise when municipality-specific time trends and census $\times$ birth cohort fixed effects are included. The coefficient of interest is now -0.0037 (standard error $=0.0013$ ) and statistically significant at less than the 1 percent level. 
In column (4), I evaluate the robustness of the results to considering an alternative source of data to assign income scores. The baseline earnings score is constructed using data from other Latin American census with available information on income. One might be concerned that these earnings scores do not accurately reflect relative incomes across industry, class of worker and gender cells in Colombia. As a robustness check, I generate an alternative income score using data from the 1973 census, the only Colombian census with information on income (see Online Appendix ?? for details). This alternative measure is highly correlated with the baseline one, with a correlation coefficient of 0.93 . Given this high correlation, the results are unsurprisingly similar in magnitude when the alternative income score is used as an outcome (column 4).

In columns (5)-(6), I explore the gender specificity of the results. As shown above, the schooling results are larger in magnitude for males than for females. Hence, if the changes observed in earnings are driven primarily by changes in completed schooling, then one should observe a similar gender heterogeneity in the effect of coffee price shocks on earnings. To examine this question, I estimate the effects of coffee price shocks on income separately for men and women. Consistent with the schooling results, I find that, although both male and female earnings significantly decline with higher childhood coffee prices, male earnings decline more than female with coefficients of -0.004 and -0.0027 , respectively.

I also examine how the long-run effects vary with children's exposure age (Table 8 and Figure 3). I find that coffee price shocks affect long-run income primarily from exposure at ages 12-15. This suggests that the mechanisms underlying the income effects vary depending on the age of exposure. It may be, for example, that the returns to secondary schooling are higher than the returns to primary schooling (Jensen, 2010). If schooling is the only mechanism driving the relationship between coffee market conditions in childhood and subsequent labor market income, then the differences in returns to schooling may explain these patterns.

In sum, the results of this section suggest that cohorts who faced sharp rises in the return to coffee-related work during school-going years have lower earnings in adulthood. The main estimate suggests that the increase in coffee prices from cohorts born in 1954 to those born in 1970 resulted in a 0.8-percent larger reduction in income in areas with one standard deviation more coffee cultivation. Performing the same counterfactual calculation as that in Section 5.2.D, I find that the boom cohort born in 1970 would have had, on average, 0.34 percent higher earnings if they had been exposed to the same coffee prices as the pre-boom cohort born in 1954. Using information on geographical mobility rates in childhood, the corresponding TOT effect is approximately 0.45 percent. 


\subsection{B Implied Returns to Schooling}

I can combine the schooling and income results to get a "back-of-the-envelope" estimate of the marginal effect of schooling on income. The baselines estimates of $\tilde{\beta}$ are -0.04 and 0.0037 for schooling and log earnings, respectively. Together, these estimates imply that the marginal effect of an extra year of schooling on income is about 10 percent $(-0.0037 /-0.04)$. This estimate is of reasonable magnitude and virtually identical to the local average treatment effect (LATE) obtained from an instrumental variable framework where the interaction between coffee cultivation intensity and childhood coffee prices is used as an instrument for schooling. Compared to well-identified studies in the literature, this implied return to schooling is well within the range of existing estimates ranging from 6 to 12 percent (Card, 1999; Acemoglu and Angrist, 2000; Duflo, 2001).

\section{Conclusion}

This paper has provided new evidence on the long-term impacts of local income shocks during school-going years. In doing so, this study exploits variation in local economic conditions in Colombia generated by dramatic fluctuations in the international price of coffee. The results indicate that cohorts who faced sharp rises in the return to coffeerelated work during school-going years completed fewer years of schooling and have lower income in adulthood. Collectively, these findings suggest that educational decisions made early in life based on local labor market conditions can have persistent impacts.

The negative effects both on long-run schooling and income are difficult to reconcile with a human capital model where education is viewed as a financial investment (Eckstein and Wolpin, 1999). Rather, these findings are consistent with the possibility that children and adolescents ignore or heavily discount the future. This behavior may be driven by credit-constrained youths rationally trading off between immediate income gains and future returns to extra schooling, with no overall welfare consequences. Alternatively, it may be that individuals drop out of school when faced with immediate income gains without realizing that in a few years their salaries will be lower than if they had stayed at school. This interpretation is made somewhat more plausible by the evidence in neurology that executive brain functions responsible for abstract reasoning, self-control and patience skills are underdeveloped among children and adolescents (Fuster, 2002; Giedd et al., 2010; Romine and Reynolds, 2005; Teffer and Semendeferi, 2012). As a consequence of poor abstract reasoning, children and adolescents may be more likely to overemphasize immediate rewards and engage in risk-taking behaviors that may lead to suboptimal outcomes (Lavecchia et al., 2016).

The present-biased behavior may be exacerbated if students focus too much on negative 
identities, in the sense that they may make educational investments based not only on their own benefits but also on immediate social gratification from their peer group (Haun et al., 2013; Lavecchia et al., 2016). If dropping out of school during booms is consistent with the behavior of some peer groups, then other students may want to do the same to conform. As a result, rises in the opportunity cost of schooling may massively increase dropout rates.

Similarly, interrupting or delaying school may create an inertia in subsequent individuals' decisions if children and adolescents rely too much on routine and automatic thinking (Lavecchia et al., 2016). In particular, employment during temporary booms may lead individuals to stick to a routine of "not attending school" even after these economic opportunities are gone. And this routine may be difficult to change. This may help explain why temporary economic shocks have persistent impacts.

The data in this study do not allow to differentiate whether the observed negative long-run outcomes reflect time-inconsistent decisions or individuals rationally trading off between immediate costs and long-term benefits from schooling. Both mechanisms may have different policy implications. In the former case, offering financial incentives to stay in school during booms may lead to improvements in welfare, but this is not necessarily true in the latter case. Further research using hypothetical questions or experimental games may provide important insights regarding this question and some possible policy prescriptions. 


\section{References}

Acemoglu, Daron, Amy Finkelstein, and Matthew J Notowidigdo, "Income and health spending: Evidence from oil price shocks," Review of Economics and Statistics, 2013, 95 (4), 1079-1095.

_ and Joshua Angrist, "How Large Are Human-Capital Externalities? Evidence from Compulsory Schooling Laws," NBER Macroeconomics Annual, 2000, 15, 9-59.

Akiyama, Takamasa, John Baffes, Donald Larson, and Panos Varangis, Commodity market reforms: lessons of two decades, The World Bank, 2001.

Almond, Douglas and Janet Currie, "Killing me softly: The fetal origins hypothesis," Journal of economic perspectives, 2011, 25 (3), 153-72.

Angrist, Joshua D and Adriana D Kugler, "Rural windfall or a new resource curse? Coca, income, and civil conflict in Colombia," The Review of Economics and Statistics, 2008, 90 (2), 191-215.

Angrist, Joshua, Eric Bettinger, Erik Bloom, Elizabeth King, and Michael Kremer, "Vouchers for private schooling in Colombia: Evidence from a randomized natural experiment," American Economic Review, 2002, 92 (5), 1535-1558.

Annan, Jeannie, Christopher Blattman, Dyan Mazurana, and Khristopher Carlson, "Civil war, reintegration, and gender in Northern Uganda," Journal of conflict resolution, 2011, 55 (6), $877-908$.

Atkin, David, "Endogenous Skill Acquisition and Export Manufacturing in Mexico," American Economic Review, August 2016, 106 (8), 2046-85.

Bacca, Renzo, "Mujeres en la caficultura tradicional colombiana, 1910-1970," Historia Y memoria, 2015, $10,43-73$.

Baird, Sarah, Joan Hamory Hicks, Michael Kremer, and Edward Miguel, "Worms at work: Long-run impacts of a child health investment," The quarterly journal of economics, 2016, 131 (4), $1637-1680$

Becker, Gary S, "Investment in human capital: A theoretical analysis," Journal of political economy, 1962, 70 (5, Part 2), 9-49.

Beegle, Kathleen, Rajeev Dehejia, and Roberta Gatti, "Why should we care about child labor? The education, labor market, and health consequences of child labor," Journal of Human Resources, 2009, 44 (4), 871-889.

Behrman, Jere R, Susan W Parker, and Petra E Todd, "Do conditional cash transfers for schooling generate lasting benefits? A five-year followup of PROGRESA/Oportunidades," Journal of Human Resources, 2011, 46 (1), 93-122.

Behrman, Jere, Susan Parker, and Petra Todd, "Innovation and Intellectual Property Rights," in "Poverty, Inequality, and Policy in Latin America" 2009, pp. 219-70.

Bernal, Raquel and Mauricio Cárdenas, "Trabajo infantil en Colombia," Technical Report, FEDESARROLLO 2006.

Black, Dan A, Terra G McKinnish, and Seth G Sanders, "Tight labor markets and the demand for education: Evidence from the coal boom and bust," ILR Review, 2005, 59 (1), 3-16.

Bleakley, Hoyt, "Malaria eradication in the Americas: A retrospective analysis of childhood exposure," American Economic Journal: Applied Economics, 2010, 2 (2), 1-45.

Blouin, Arthur and Rocco Macchiavello, "Strategic Default in the International Coffee Market," The Quarterly Journal of Economics, forthcoming.

Cameron, A. Colin, Jonah B. Gelbach, and Douglas L. Miller, "Bootstrap-Based Improvements for Inference with Clustered Errors," The Review of Economics and Statistics, 2008, 90 (3), $414-427$.

Card, David, "Chapter 30 - The Causal Effect of Education on Earnings," in Orley C. Ashenfelter and David Card, eds., Orley C. Ashenfelter and David Card, eds., Vol. 3 of Handbook of Labor Economics, Elsevier, 1999, pp. $1801-1863$. 
Caviedes, Cesar, "Natural Hazards in Latin America: A Survey and Discussion," Proceedings of the Conference of Latin Americanist Geographers, 1981, 8, 280-294.

Chaisemartin, Clément De and Xavier D'HaultfEuille, "Fuzzy differences-in-differences," The Review of Economic Studies, 2017, 85 (2), 999-1028.

Charles, Kerwin Kofi, Erik Hurst, and Matthew J Notowidigdo, "Housing Booms and Busts, Labor Market Opportunities, and College Attendance," American Economic Review, Forthcoming.

Chetty, Raj and Nathaniel Hendren, "The impacts of neighborhoods on intergenerational mobility I: Childhood exposure effects," The Quarterly Journal of Economics, 2018, 133 (3), 1107-1162.

_ , John N Friedman, and Jonah E Rockoff, "Measuring the impacts of teachers II: Teacher valueadded and student outcomes in adulthood," American Economic Review, 2014, 104 (9), 2633-79.

_ , _ , Nathaniel Hilger, Emmanuel Saez, Diane Whitmore Schanzenbach, and Danny Yagan, "How does your kindergarten classroom affect your earnings? Evidence from Project STAR," The Quarterly Journal of Economics, 2011, 126 (4), 1593-1660.

$\ldots, \ldots, \ldots, \ldots, \ldots$, and $\ldots$, "How does your kindergarten classroom affect your earnings? Evidence from Project STAR," The Quarterly Journal of Economics, 2011, 126 (4), 1593-1660.

Clifford, Michael and Ken Wilson, Coffee: Botany, Biochemistry and Production of Beans and Beverage 1985 .

Crabtree, John, Peru under Garcia: An opportunity lost, Springer, 2016.

Cunha, Flavio and James Heckman, "The technology of skill formation," American Economic Review, 2007, $97(2), 31-47$.

de Graaff, Jan, The economics of coffee., (Wageningen: Centre for Agricultural Publishing and Documentation), 1986.

Dube, Oeindrila and Juan F Vargas, "Commodity price shocks and civil conflict: Evidence from Colombia," The Review of Economic Studies, 2013, 80 (4), 1384-1421.

Duflo, Esther, "Schooling and labor market consequences of school construction in Indonesia: Evidence from an unusual policy experiment," American economic review, 2001, 91 (4), 795-813.

Echeverry, Ernesto Gómez, Olga Inés Ceballos Rincón, Luis Carlos Buitrago Rodríguez, and Cristian Manuel Páez Benítez, "Cadena productiva del café: demanda de trabajo para población vulnerable en el departamento del Quindío," Contexto, 2013, 2 (1), 11-31.

Eckstein, Zvi and Kenneth I Wolpin, "Why youths drop out of high school: The impact of preferences, opportunities, and abilities," Econometrica, 1999, 67 (6), 1295-1339.

Edmonds, Eric V and Nina Pavcnik, "The effect of trade liberalization on child labor," Journal of international Economics, 2005, 65 (2), 401-419.

_ and _ , "International trade and child labor: cross-country evidence," Journal of International Economics, 2006, 68 (1), 115-140.

_ , _ , and Petia Topalova, "Trade adjustment and human capital investments: Evidence from Indian tariff reform," American Economic Journal: Applied Economics, 2010, 2 (4), 42-75.

Emery, JC Herbert, Ana Ferrer, and David Green, "Long-term consequences of natural resource booms for human capital accumulation," Industrial and Labor Relations Review, 2012, 65 (3), 708-734.

Ferreira, Francisco and Norbert Schady, "Do Macroeconomic Crises Always Slow Human Capital Accumulation?," The World Bank Economic Review, 2004, 18 (2), 131-154.

_ and _, "Aggregate Economic Shocks, Child Schooling, and Child Health," World Bank Research Observer, 2009, 24 (2), 147-181. 
Funkhouser, Edward, "Cyclical economic conditions and school attendance in Costa Rica," Economics of Education Review, 1999, 18 (1), 31-50.

Fuster, Joaquín M, "Frontal lobe and cognitive development," Journal of neurocytology, 2002, 31 (3-5), 373-385.

Giedd, Jay N, Michael Stockman, Catherine Weddle, Maria Liverpool, Aaron AlexanderBloch, Gregory L Wallace, Nancy R Lee, Francois Lalonde, and Rhoshel K Lenroot, "Anatomic magnetic resonance imaging of the developing child and adolescent brain and effects of genetic variation," Neuropsychology review, 2010, 20 (4), 349-361.

Giovannucci, Daniele, José Leibovich, Diego Pizano, Gonzalo Paredes, Santiago Montenegro, Hector Arévalo, and Panos Varangis, "Colombia : Coffee Sector Study 2002," Technical Report, World Bank 2002.

Gómez, David Ricardo, "Condiciones laborales en el sector cafetero: la jornada, el salario y el descanso: El caso del municipio de Andes, Antioquia," B.S. thesis, Universidad EAFIT 2013.

Haun, Daniel BM, Edwin JC Van Leeuwen, and Micah G Edelson, "Majority influence in children and other animals," Developmental cognitive neuroscience, 2013, 3, 61-71.

Hausmann, Ricardo and Roberto Rigobon, "An Alternative Interpretation of the 'Resource Curse': Theory and Policy Implications," Working Paper 9424, National Bureau of Economic Research 2003.

Hübner, Malte, "Do tuition fees affect enrollment behavior? Evidence from a 'natural experiment'in Germany," Economics of Education Review, 2012, 31 (6), 949-960.

ILA, "List of goods produced by child labor or forced labor," 2009.

Jensen, Robert, "The (perceived) returns to education and the demand for schooling," The Quarterly Journal of Economics, 2010, 125 (2), 515-548.

Johnson, Matthew T., "Borrowing Constraints, College Enrollment, and Delayed Entry," Journal of Labor Economics, 2013, 31 (4), 669-725.

Krueger, Alan B, "Experimental estimates of education production functions," The quarterly journal of economics, 1999, 114 (2), 497-532.

Kruger, Diana I., "Coffee production effects on child labor and schooling in rural Brazil," Journal of Development Economics, 2007, 82 (2), 448 - 463.

Lavecchia, Adam M, Heidi Liu, and Philip Oreopoulos, "Behavioral economics of education: Progress and possibilities," in "Handbook of the Economics of Education," Vol. 5, Elsevier, 2016, pp. 174.

Light, Audrey, "The effects of interrupted schooling on wages," Journal of Human Resources, 1995, pp. $472-502$.

Lleras-Muney, Adriana, "The Relationship between Education and Adult Mortality in the United States," The Review of Economic Studies, 2005, 72 (1), 189-221.

Lochner, Lance and Alexander Monge-Naranjo, "Credit constraints in education," Annual Review of Economics, 2012, 4 (1), 225-256.

- and Enrico Moretti, "The effect of education on crime: Evidence from prison inmates, arrests, and self-reports," American economic review, 2004, 94 (1), 155-189.

Macchiavello, Rocco and Ameet Morjaria, "Competition and relational contracts: evidence from Rwanda's coffee mills," 2017.

Maccini, Sharon and Dean Yang, "Under the weather: Health, schooling, and economic consequences of early-life rainfall," American Economic Review, 2009, 99 (3), 1006-26.

Miller, Grant and B Piedad Urdinola, "Cyclicality, mortality, and the value of time: The case of coffee price fluctuations and child survival in Colombia," Journal of Political Economy, 2010, 118 (1), 113-155. 
National Federation of Coffee Growers, "Situación de los menores de edad de familias cafeteras colombianas con relación al trabajo infantil," 2011.

Nguyen, Hoa and Ulrike Grote, "Agricultural Policies in Vietnam : Producer Support Estimates, 1986-2002," 022004.

Oreopoulos, Philip, "Do dropouts drop out too soon? Wealth, health and happiness from compulsory schooling," Journal of public Economics, 2007, 91 (11-12), 2213-2229.

Partners of the Americas, "Colombia Avanza," 2018.

Rocha, Rudi and Rodrigo R Soares, "Water scarcity and birth outcomes in the Brazilian semiarid," Journal of Development Economics, 2015, 112, 72-91.

Romine, Cassandra B and Cecil R Reynolds, "A model of the development of frontal lobe functioning: Findings from a meta-analysis," Applied neuropsychology, 2005, 12 (4), 190-201.

Rosenzweig, Mark R. and Robert Evenson, "Fertility, Schooling, and the Economic Contribution of Children of Rural India: An Econometric Analysis," Econometrica, 1977, 45 (5), 1065-1079.

Sachs, Jeffrey D and Andrew M Warner, "Natural Resource Abundance and Economic Growth," Working Paper 5398, National Bureau of Economic Research 1995.

Sala-i-Martin, Xavier and Arvind Subramanian, "Addressing the Natural Resource Curse: An Illustration from Nigeria," Working Paper 9804, National Bureau of Economic Research 2003.

Shah, Manisha and Bryce Millett Steinberg, "Drought of Opportunities: Contemporaneous and Long-Term Impacts of Rainfall Shocks on Human Capital," Journal of Political Economy, 2017, 125 (2), $527-561$.

Soares, Rodrigo R., Diana Kruger, and Matias Berthelon, "Household Choices of Child Labor and Schooling: A Simple Model with Application to Brazil," Journal of Human Resources, 2012, 47 (1), 1-31.

Stuart, Bryan, "The Long-Run Effects of Recessions on Education and Income," Technical Report, US Census Bureau, Center for Economic Studies 2017.

Sviatschi, Maria Micaela, "Making a Narco: childhood exposure to illegal labor markets and criminal life paths," Unpublished manuscript, Columbia University, 2019.

Teffer, Kate and Katerina Semendeferi, "Human prefrontal cortex: evolution, development, and pathology," in "Progress in brain research," Vol. 195 2012, pp. 191-218.

Thomas, Duncan, Kathleen Beegle, Elizabeth Frankenberg, Bondan Sikoki, John Strauss, and Graciela Teruel, "Education in a Crisis," Journal of Development economics, 2004, 74 (1), 53-85.

Tsui, Kevin K, "More oil, less democracy: evidence from worldwide crude oil discoveries," The Economic Journal, 2010, 121 (551), 89-115.

United Nations Development Program, Sector Cafés Especiales: Perfiles Ocupacionales para la Cadena Productiva de cafés Especiales 2014. 


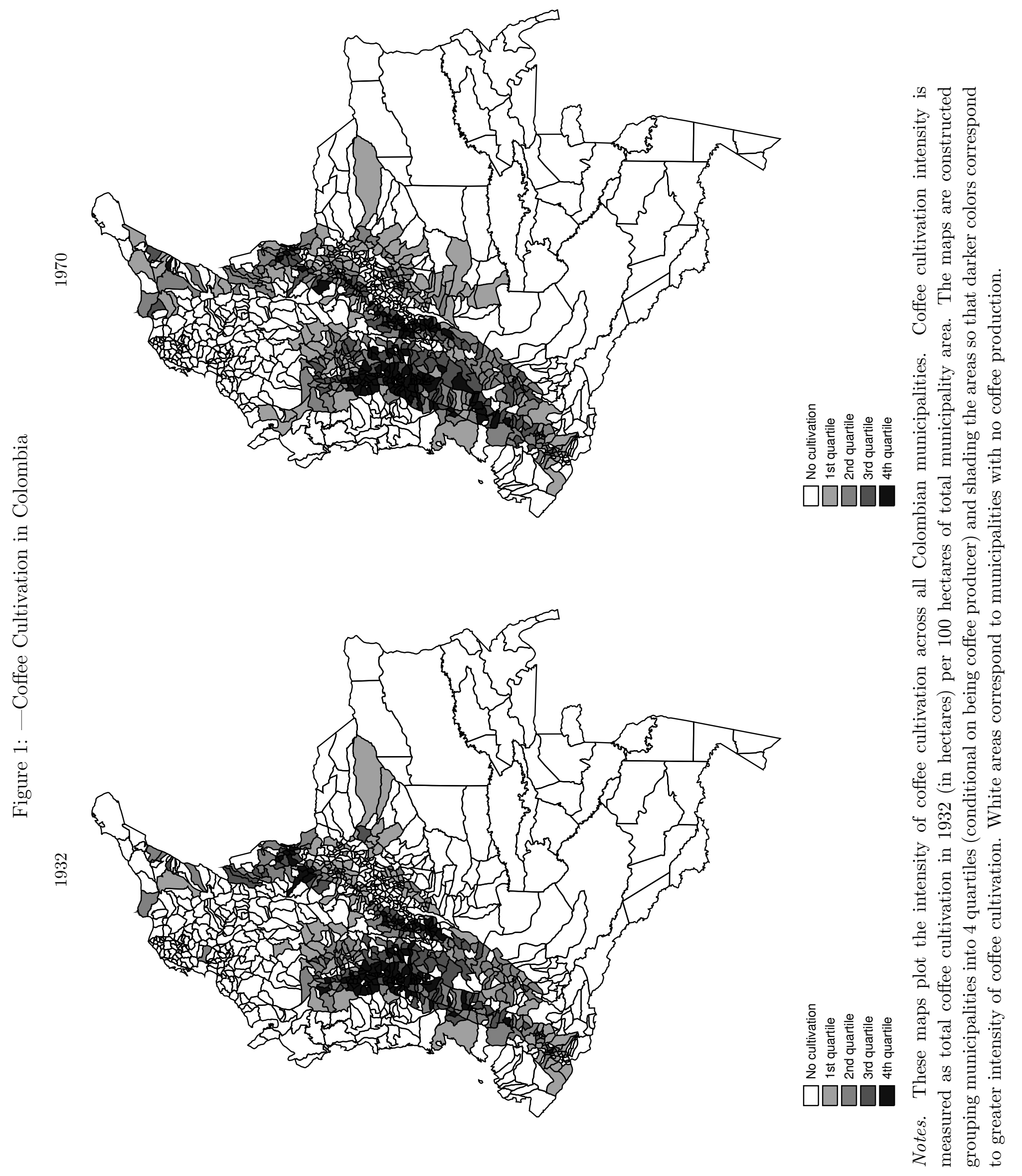


Figure 2: —Real International and Internal Coffee Prices

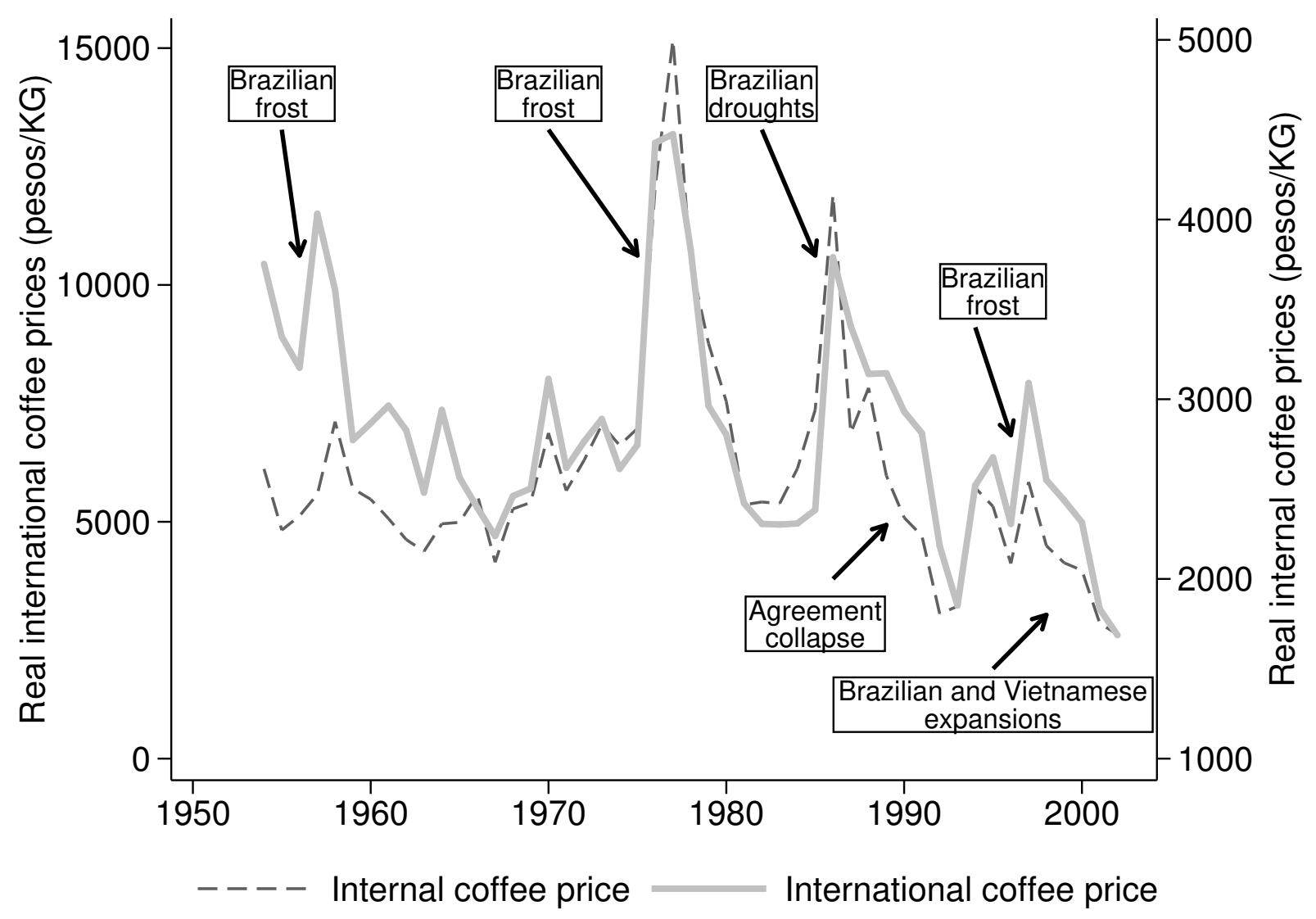


Figure 3: —Distribution of Coffee Cultivation Intensities in 1932 and 1970

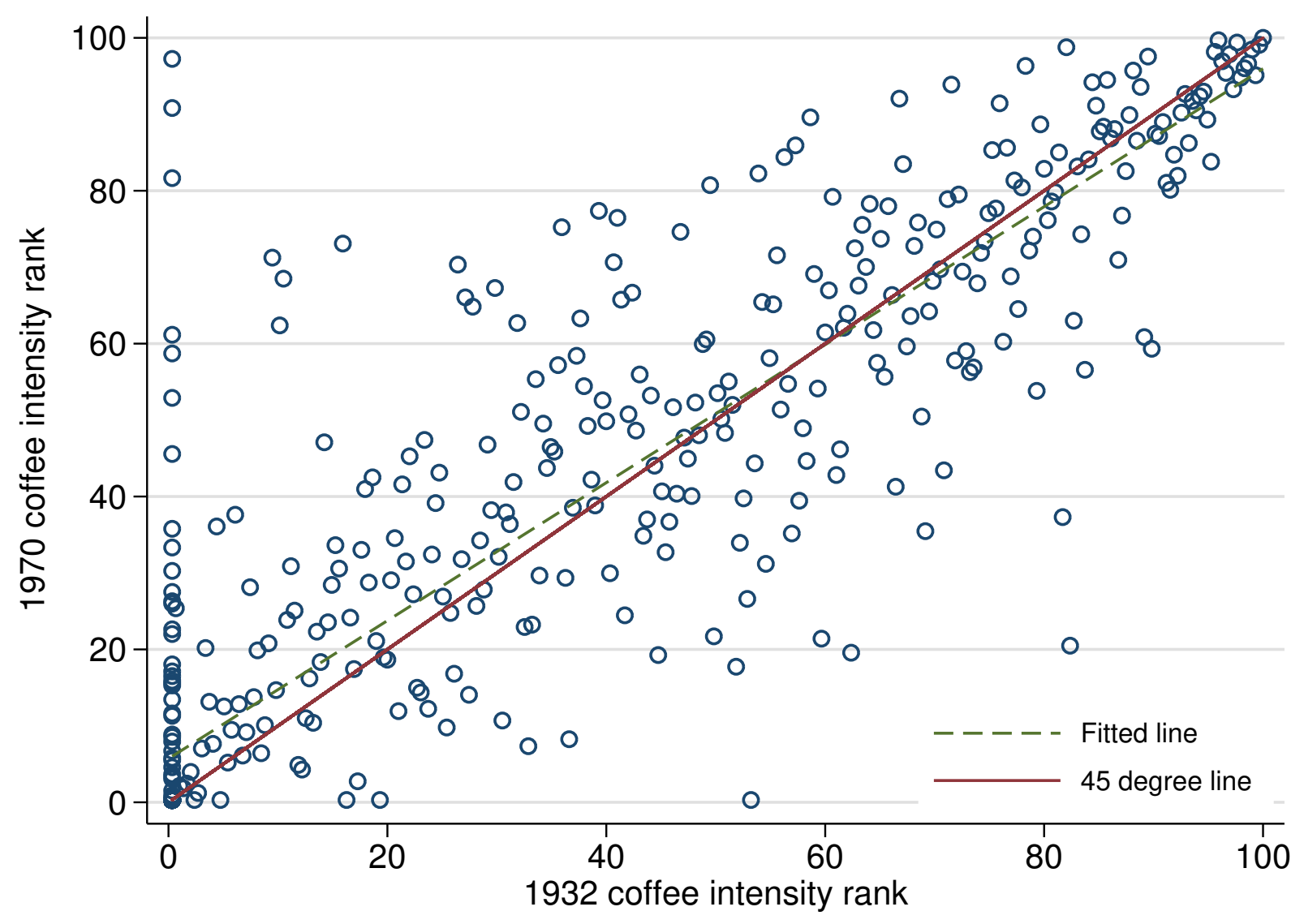

Notes. The points on the figure plot the coffee cultivation percentile ranks of Colombian municipalities in 1970 and 1932. The best-fit line is estimated using an OLS regression on the underlying municipality-level data. The estimated slope of this regression is 0.90 (standard error $=0.02$ ). Coffee cultivation intensity is defined as the total hectares of land used for cultivating coffee in the municipality divided by the total land area. There are 531 municipalities. 
Figure 4: — School-Age Coffee Prices and Completed Schooling

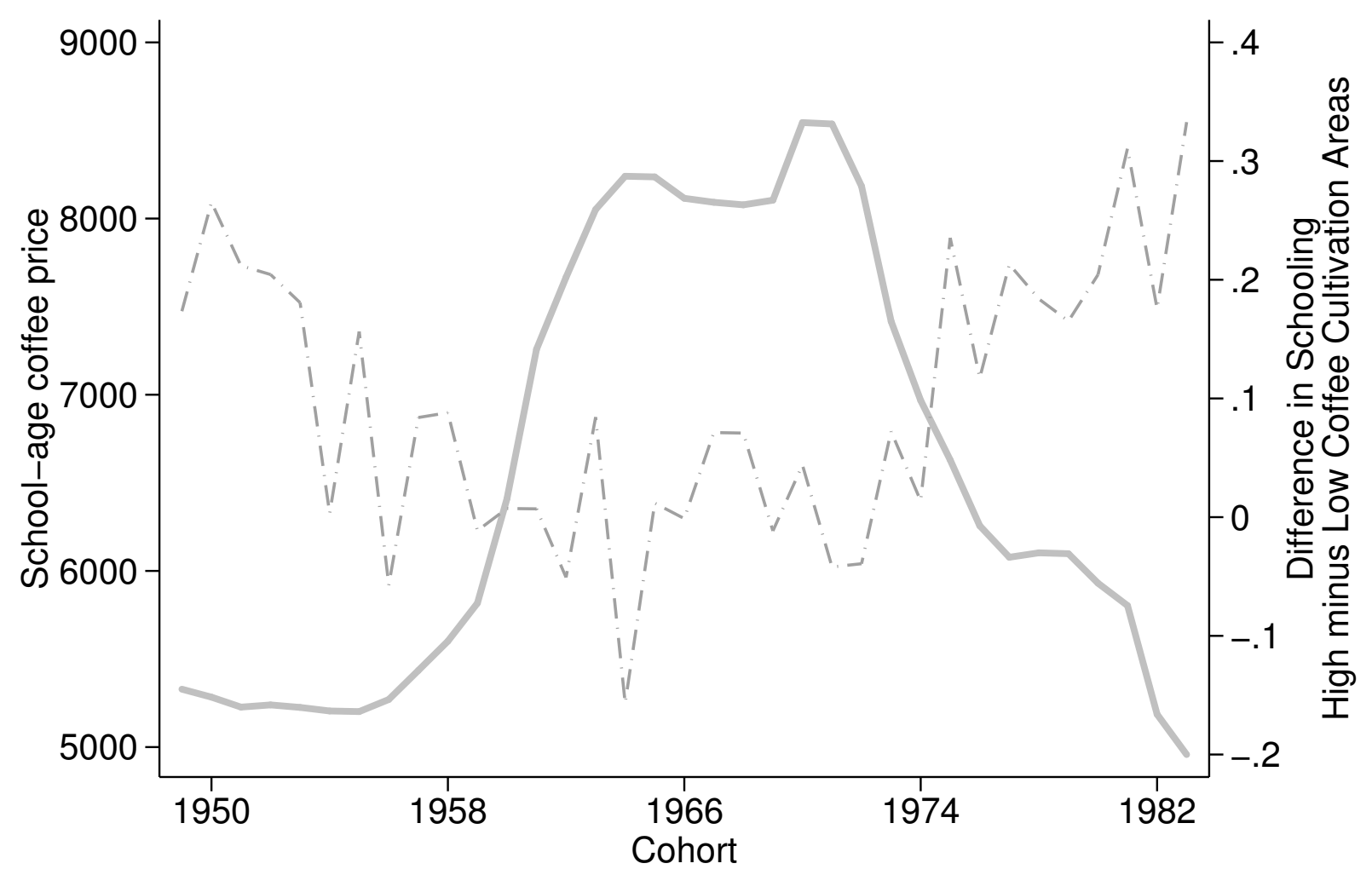

School-age coffee price - - - - Difference in schooling

Notes. High coffee cultivation areas correspond to those cohorts born in municipalities above the 75th percentile of the coffee cultivation distribution. Analogously, low coffee cultivation areas correspond to those in municipalities below the 75th percentile of the coffee cultivation distribution. The figure plots the difference in mean years of schooling between cohorts born in high and low coffee cultivation areas. It also plots the school-age coffee price for each birth cohort. The schoolage coffee price of the cohort born in year $t$ corresponds to the average coffee price observed between the years $t+5$ and $t+16$. The sample contains cohorts born between 1949 and 1983, who are 22-56 years old at the time they are observed in the census. There are 531 municipalities. 
Figure 5: - Cohort Schooling and Coffee Cultivation

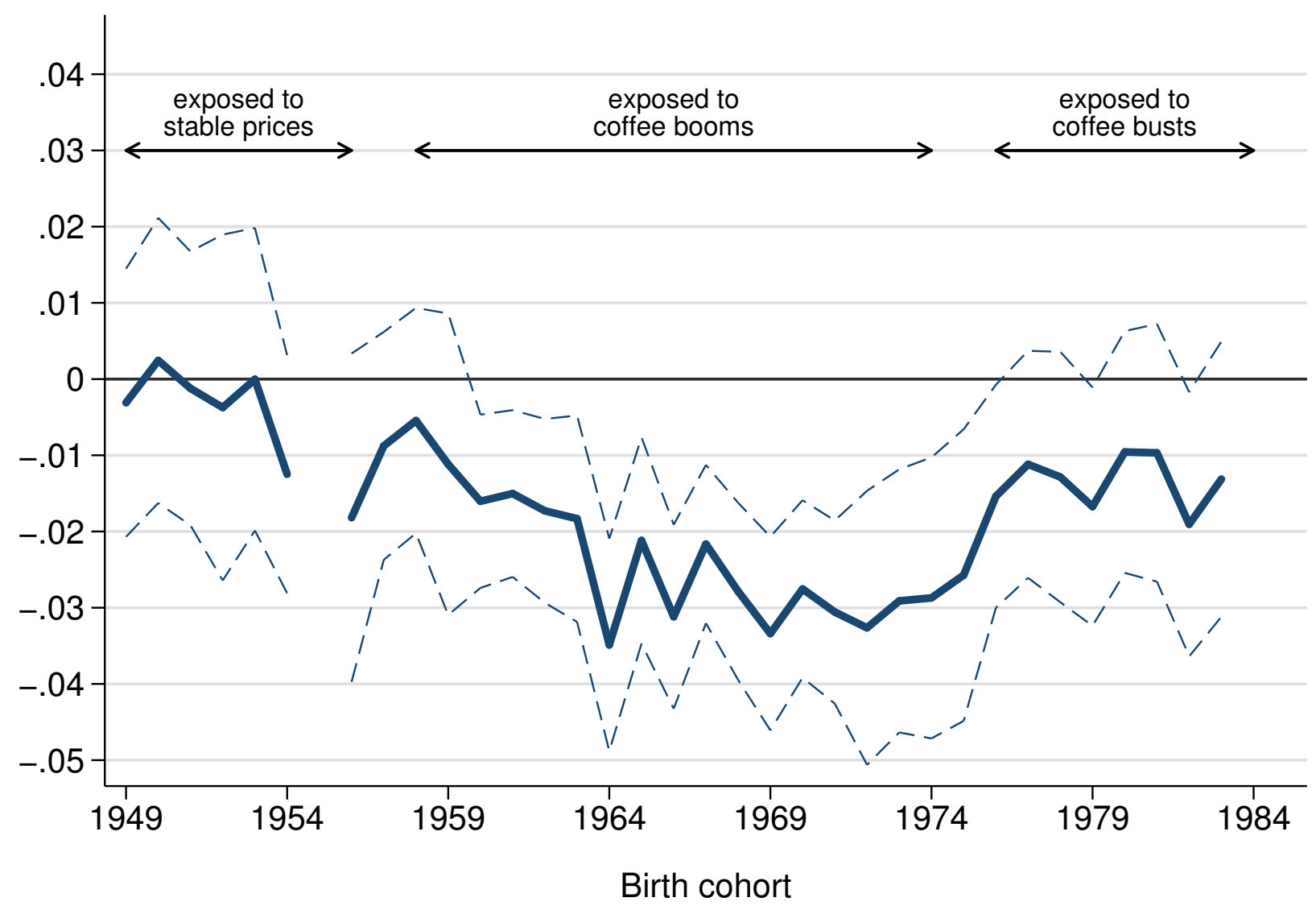

Notes. This figure presents estimates of $\tilde{\beta}^{t}$ from $S_{j t c}=\tilde{\alpha}+\sum_{t=1949}^{1983} \tilde{\beta}^{t}\left(\mathbf{1}(t=\tau) \times \mathbb{I}_{j}\right)+\tilde{\lambda}_{j}+\tilde{\mu}_{c t}+\tilde{\xi}_{j t c}$. The omitted group is the 1955 birth cohort. Dependent variable is average years of schooling for cohort $t$ born in municipality $j$ observed in census year $c$. Coffee cultivation intensity is given by $\mathbb{I}_{j}$, which is measured as total coffee cultivation in 1932 (in hectares) per 100 hectares of total municipality area. The specification includes municipality fixed effects, $\lambda_{j}$, and cohort $\times$ census-year fixed effects, $\mu_{c t}$. Sample includes individuals born between 1949 and 1983 who are 22-56 years old at census time. Microdata are collapsed into municipality-cohort-census cells and regressions are weighted by the square root of cell size. There are 531 municipalities. The total number of observations is 64234. Robust standard errors are clustered at the municipality level. Dashed lines plots 95 percent confidence intervals for estimates of $\beta^{t}$. 
Figure 6: -Effects of Coffee Price Shocks on Completed Schooling

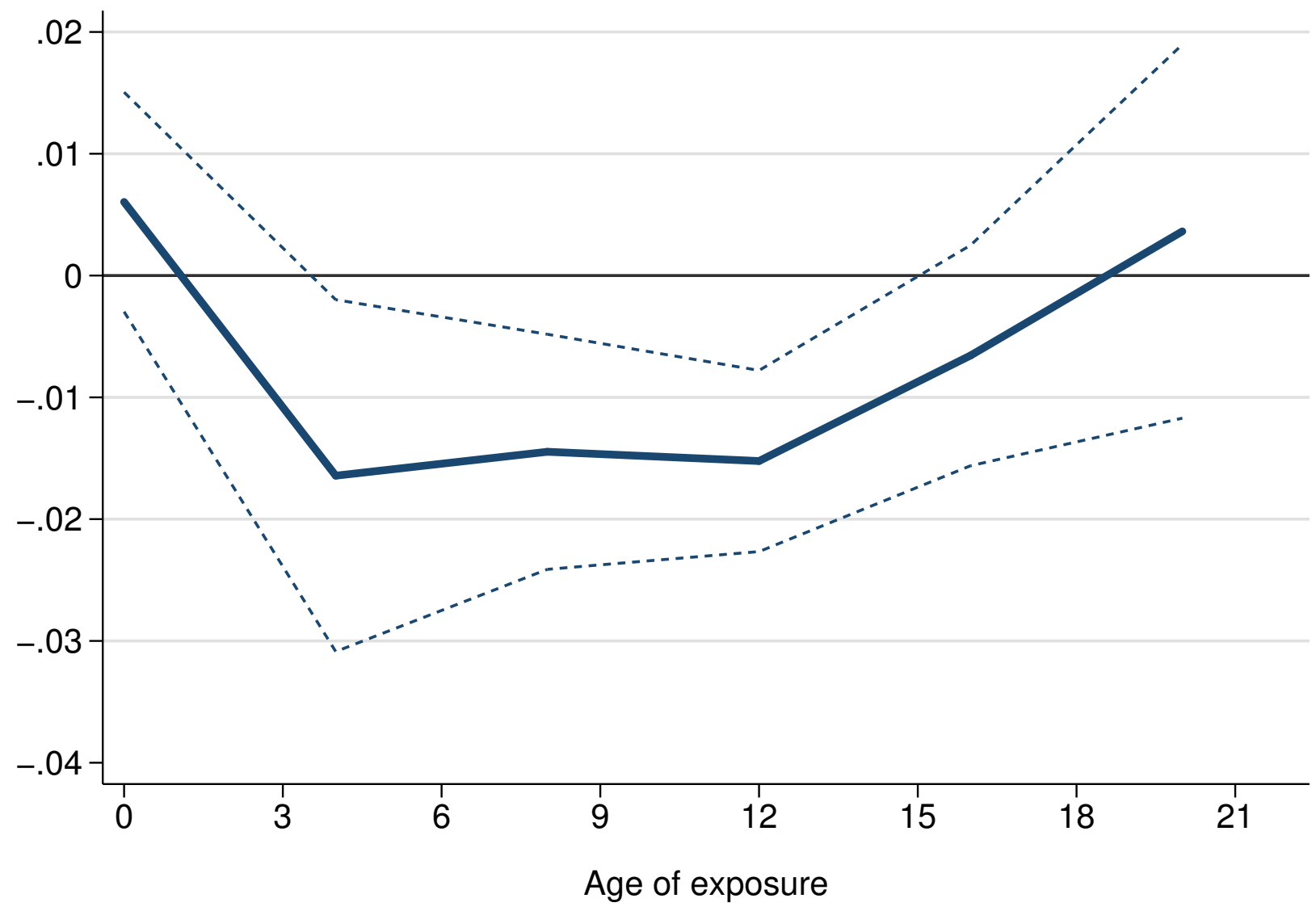

Notes. This figure plots estimates of the effects of coffee price shocks at different ages of exposure on years of education. It shows estimates of $\tilde{\beta}^{a}$ from model (3). The regression includes controls for municipality-of-birth, year-of-birth-by-census-year and gender fixed effects as well as municipalityspecific linear time trends. Coffee cultivation intensity is measured as total coffee cultivation in 1932 (in hectares) per 100 hectares of total municipality area. The dashed lines represent the respective 95 percent confidence intervals, where robust standard errors are clustered at the municipality-level. I group ages to increase precision: 0-1, 2-5, 6-9, 10-13, 14-17, 18-21. Sample includes individuals born between 1949 and 1983 who are 22-56 years old at census time. Microdata are collapsed into municipality-cohort-census cells and regressions are weighted by the square root of cell size. There are 531 municipalities. The total number of observations is 64234 . 
Figure 7: —Effects of Coffee Price Shocks on (log) Industrial Income Score

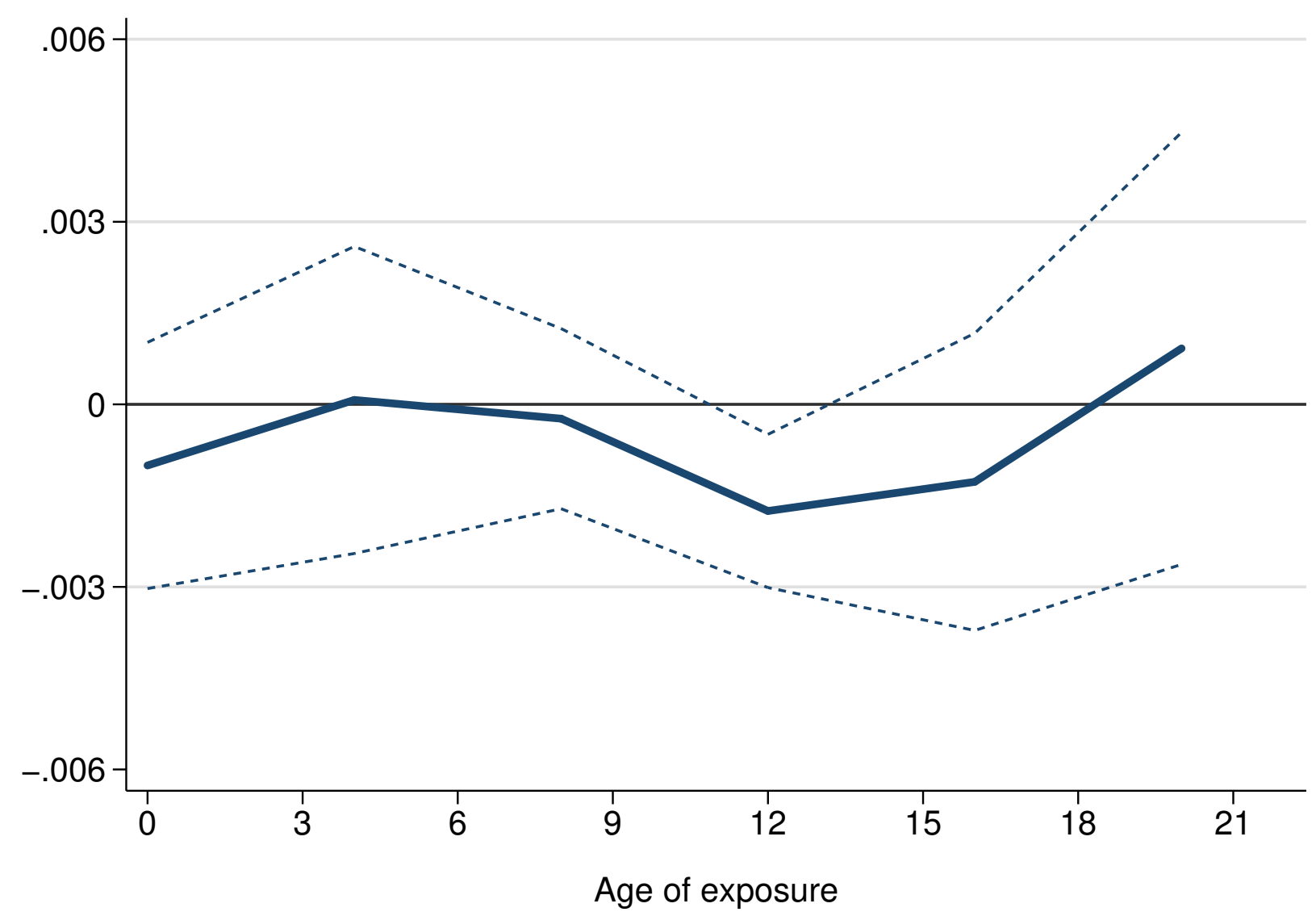

Notes. This figure plots estimates of the effects of coffee price shocks at different ages of exposure on ( $\log )$ industrial earnings score. It shows estimates of $\tilde{\beta}^{a}$ from model (3). The regression includes controls for municipality-of-birth, year-of-birth-by-census-year and gender fixed effects as well as municipality-specific linear time trends. Coffee cultivation intensity is measured as total coffee cultivation in 1932 (in hectares) per 100 hectares of total municipality area. The dashed lines represent the respective 95 percent confidence intervals, where robust standard errors are clustered at the municipality-level. I group ages to increase precision: 0-1, 2-5, 6-9, 10-13, 14-17, 18-21. Sample includes individuals born between 1949 and 1983 who are 22-56 years old at census time. Microdata are collapsed into municipality-cohort-census cells and regressions are weighted by the square root of cell size. There are 531 municipalities. The total number of observations is 61472 . 
Table 1: Summary Statistics

\begin{tabular}{lccc}
\hline \hline & \multicolumn{3}{c}{ Standard } \\
& $\begin{array}{c}\text { Mean } \\
\text { Deviation } \\
(1)\end{array}$ & $\begin{array}{c}(2) \\
\text { observations } \\
(3)\end{array}$ \\
\hline Panel A: Adults aged 22-56 & & & \\
Total years of education & 7.50 & 2.29 & 64482 \\
(log) Industrial income score & -0.05 & 0.25 & 61693 \\
Age & 34.36 & 9.05 & 64505 \\
Sex: female=1 & 0.52 & 0.50 & 64505 \\
Log School-age coffee price (ages 5 to 16) & 8.80 & 0.19 & 64505 \\
Coffee cultivation intensity & 1.96 & 4.50 & 64257 \\
Panel B: Children aged 5-16 & & & \\
School attendance (=1) & 0.80 & 0.17 & 3035 \\
Child labor (=1) & 0.05 & 0.07 & 2102 \\
Age & 10.46 & 3.45 & 3038 \\
Sex: female=1 & 0.50 & 0.50 & 3038 \\
\hline \hline
\end{tabular}

Notes. Panel A contains summary statistics using 1973, 1993, and 2005 censuses aggregated at the municipality-of-birth, year-of-birth, sex and census-year level. The observations are weighted by the number of observations in each cell. The sample contains cohorts born between 1949 and 1983, who are 22-56 years old at the time they are observed in the census. Panel B contains summary statistics using 1973, 1985, and 1993 aggregated at the department, censusyear, age, and sex level. Child labor is only available for children over 10 years old. Coffee cultivation intensity is measured as total coffee cultivation in 1932 (in hectares) per 100 hectares of total municipality area. 
Table 2: Coffee Price Shocks and School Attendance, Enrollment, and Child Labor

\begin{tabular}{|c|c|c|c|c|c|}
\hline & \multicolumn{5}{|c|}{ Dependent variable: } \\
\hline & \multicolumn{3}{|c|}{ School attendance } & \multirow{2}{*}{$\begin{array}{c}\text { Enrollment rates } \\
\text { period: } 1954-1977 \\
(4)\end{array}$} & \multirow{2}{*}{$\begin{array}{c}\text { Child labor } \\
\text { ages: } 10-16 \\
(5)\end{array}$} \\
\hline & $\begin{array}{c}\text { ages: } 5-16 \\
(1)\end{array}$ & $\begin{array}{c}\text { ages: 5-11 } \\
(2)\end{array}$ & $\begin{array}{c}\text { ages: } 12-16 \\
(3)\end{array}$ & & \\
\hline $\log$ coffee price $\times$ & -0.0112 & -0.0112 & -0.011 & -0.0909 & 0.0033 \\
\hline \multirow[t]{2}{*}{ coffee cultivation intensity } & {$[0.0027]^{* * *}$} & {$[0.0026]^{* * *}$} & {$[0.0032]^{* * *}$} & {$[0.0320]^{* * *}$} & {$[0.0012]^{* * *}$} \\
\hline & $(0.000)$ & $(0.000)$ & $(0.000)$ & - & $(0.000)$ \\
\hline Observations & 2203 & 1283 & 920 & 486 & 1287 \\
\hline$R^{2}$ & 0.9396 & 0.959 & 0.8717 & 0.8508 & 0.8275 \\
\hline
\end{tabular}

Notes. Coffee cultivation intensity is measured as total coffee cultivation in 1932 (in hectares) per 100 hectares of total land area. School attendance and child labor results are based on 1973, 1985 and 1993 census data on children in rural areas aggregated at the the department/census-year/cohort/gender level, and the observations are weighted by the square root of the cell sizes. These regressions include controls for department-specific time trends, and department, gender, census-year and cohort-census fixed effects. Enrollment rates represent children in primary-schools divided by $5-11$ children. This variable is at the department/year level. Column (4) includes controls for department and year fixed effects as well as departmentspecific linear time trends, and weights the observations by the square root of the number of 5-11 children. Robust standard errors (in brackets) are clustered at the department level. Two-tailed $p$-values based on the wild cluster bootstrap- $T$ method in parentheses. There are 33 departments in columns (1)-(3) and (5), and 22 departments in column (4). The number of departments differ because some departments are grouped with neighboring departments in the formal education statistics, the source for school enrollment data.

$* * *$ Significant at the 1 percent level.

**Significant at the 5 percent level.

*Significant at the 10 percent level. 
Table 3: Coffee Price Shocks and Completed Schooling

\begin{tabular}{|c|c|c|c|c|}
\hline & \multicolumn{4}{|c|}{$\begin{array}{c}\text { Dependent variable: } \\
\text { years of education attained }\end{array}$} \\
\hline & No controls & $\begin{array}{l}\text { Add municipality } \times \\
\text { linear trends }\end{array}$ & $\begin{array}{c}\text { Add census } \times \\
\text { cohort } \\
\text { fixed effects }\end{array}$ & $\begin{array}{c}\text { Add census } \times \\
\text { municipality } \\
\text { fixed effects }\end{array}$ \\
\hline & (1) & $(2)$ & $(3)$ & (4) \\
\hline $\begin{array}{l}\text { log school-age coffee price } \times \\
\text { coffee cultivation intensity }\end{array}$ & $\begin{array}{c}-0.047 \\
{[0.0132]^{* * *}}\end{array}$ & $\begin{array}{c}-0.0404 \\
{[0.0094]^{* * *}}\end{array}$ & $\begin{array}{c}-0.04 \\
{[0.0093]^{* * *}}\end{array}$ & $\begin{array}{c}-0.0382 \\
{[0.0097]^{* * *}}\end{array}$ \\
\hline Observations & 64234 & 64234 & 64234 & 64234 \\
\hline$R^{2}$ & 0.7157 & 0.7291 & 0.7319 & 0.7482 \\
\hline & $\begin{array}{c}\text { Drop } 1993 \text { census } \\
\text { observations }\end{array}$ & $\begin{array}{l}\text { Cap at } \\
12 \text { years }\end{array}$ & & \\
\hline & $(5)$ & (6) & & \\
\hline $\begin{array}{l}\text { log school-age coffee price } \times \\
\text { coffee cultivation intensity }\end{array}$ & $\begin{array}{c}-0.0424 \\
{[0.0126]^{* * *}}\end{array}$ & $\begin{array}{c}-0.034 \\
{[0.0093]^{* * *}}\end{array}$ & & \\
\hline Observations & 40084 & 64234 & & \\
\hline$R^{2}$ & 0.725 & 0.7455 & & \\
\hline
\end{tabular}

Notes. Dependent variable is total years of education attained. School-age coffee price of the cohort born in year $t$ is the average real world coffee price observed between years $t+5$ and $t+16$. Coffee cultivation intensity is measured as total coffee cultivation in 1932 (in hectares) per 100 hectares of total municipality area. Sample restricted to 1973, 1993 and 2005 census data on individuals born between 1949 and 1983, who are 22-56 years old at the time they are observed in the census. The data are collapsed into municipality-of-birth, year-of-birth, sex and census-year cells, and the observations are weighted by the square root of the cell sizes. There are 531 municipalities. All regressions include controls for municipalityof-birth, year-of-birth, census-year and gender fixed effects. Robust standard errors (in brackets) are clustered at the municipality level.

$* * *$ Significant at the 1 percent level.

**Significant at the 5 percent level.

*Significant at the 10 percent level. 
Table 4: Coffee Price Shocks and Completed Schooling (Reduced-form and Instrumental Variable Estimates)

\begin{tabular}{|c|c|c|c|c|}
\hline & \multicolumn{4}{|c|}{$\begin{array}{l}\text { Dependent variable: } \\
\text { years of education attained }\end{array}$} \\
\hline & Baseline & $\begin{array}{l}\text { Reduced-form } \\
\text { estimates }\end{array}$ & $\begin{array}{l}\text { First-stage } \\
\text { estimates }\end{array}$ & $\begin{array}{c}\text { Instrumental variable } \\
\text { estimates }\end{array}$ \\
\hline & $(1)$ & $(2)$ & $(3)$ & $(4)$ \\
\hline $\begin{array}{l}\text { log school-age coffee price } \times \\
\text { coffee cultivation intensity }\end{array}$ & $\begin{array}{c}-0.04 \\
{[0.0093]^{* * *}}\end{array}$ & & & $\begin{array}{c}-0.0345 \\
{[0.0094]^{* * *}}\end{array}$ \\
\hline $\begin{array}{l}\text { log school-age Brazilian coffee production } \times \\
\text { coffee cultivation intensity }\end{array}$ & & $\begin{array}{c}0.0446 \\
{[0.0122]^{* * *}}\end{array}$ & $\begin{array}{c}-1.293 \\
{[0.1158]^{* * *}}\end{array}$ & \\
\hline F-stat excluded instrument & & & 160900.5 & \\
\hline Observations & 64234 & 64234 & 64234 & 64234 \\
\hline
\end{tabular}

Notes. Column (1) reports the baseline estimate based on equation (2). Column (2) repeats equation (2), but uses Brazilian coffee production rather coffee prices. Column (4) reports two-stage least squares, where (log) schoolage Brazilian coffee production $\times$ coffee cultivation intensity is used as an instrument for $(\log )$ school-age coffee prices $\times$ coffee cultivation intensity. The first stage is reported in column (3). School-age coffee price of the cohort born in year $t$ is the average real world coffee price observed between years $t+5$ and $t+16$. Similarly, school-age Brazilian coffee production of the cohort born in year $t$ is the average Brazilian coffee production observed between years $t+5$ and $t+16$. Coffee cultivation intensity is measured as total coffee cultivation in 1932 (in hectares) per 100 hectares of total municipality area. Sample restricted to 1973, 1993 and 2005 census data on individuals born between 1949 and 1983, who are 22-56 years old at the time they are observed in the census. The data are collapsed into municipality-of-birth, year-of-birth, sex and census-year cells, and the observations are weighted by the square root of the cell sizes. All regressions include controls for municipality-of-birth, year-of-birth-by-census-year and gender fixed effects as well as municipality-specific linear time trends. Robust standard errors (in brackets) are clustered at the municipality level. There are 531 municipalities.

*** Significant at the 1 percent level.

** Significant at the 5 percent level.

*Significant at the 10 percent level. 
Table 5: Coffee Price Shocks and Child Labor, and Schooling (Gender Heterogeneities)

\begin{tabular}{|c|c|c|c|c|}
\hline & \multicolumn{4}{|c|}{ Dependent variable: } \\
\hline & \multicolumn{2}{|c|}{ Child labor } & \multicolumn{2}{|c|}{ Educational attainment } \\
\hline & male & female & male & female \\
\hline & (1) & $(2)$ & $(3)$ & $(4)$ \\
\hline $\begin{array}{l}\log \text { coffee price } \times \\
\text { coffee cultivation intensity }\end{array}$ & $\begin{array}{c}0.0053 \\
{[0.0015]^{* * *}} \\
(0.000)\end{array}$ & $\begin{array}{c}0.0019 \\
{[0.0011]^{*}} \\
(0.000)\end{array}$ & & \\
\hline $\begin{array}{l}\text { log school-age coffee price } \times \\
\text { coffee cultivation intensity }\end{array}$ & & & $\begin{array}{c}-0.0528 \\
{[0.0110]^{* * *}}\end{array}$ & $\begin{array}{c}-0.0287 \\
{[0.0094]^{* * *}}\end{array}$ \\
\hline Observations & 646 & 641 & 32115 & 32119 \\
\hline$R^{2}$ & 0.901 & 0.8698 & 0.7249 & 0.7677 \\
\hline
\end{tabular}

Notes. Coffee cultivation intensity is measured as total coffee cultivation in 1932 (in hectares) per 100 hectares of total land area. Columns (1)-(2) are from a sample restricted to 1973, 1985 and 1993 census data on children in rural areas aggregated at the the department/census-year/cohort/gender level, and the observations are weighted by the square root of the cell sizes. Columns (3)-(4) are from a sample restricted to 1973, 1993 and 2005 census on individuals born between 1949 and 1983 who are 22-56 years old at census time. These data are aggregated at the municipalityof-birth/cohort/gender/census-year level, and the observations are weighted by the square root of the cell sizes. Two-tailed $p$-values based on the wild cluster bootstrap$T$ method in parentheses. There are 33 departments in columns (1)-(2) and $531 \mathrm{mu}-$ nicipalities in columns (3)-(4).

***Significant at the 1 percent level.

**Significant at the 5 percent level.

*Significant at the 10 percent level. 
Table 6: Effects of Coffee Prices on Teacher Rates Adult Employment

\begin{tabular}{lcc}
\hline \hline & \multicolumn{2}{c}{ Dependent variable: } \\
\cline { 2 - 3 } & $\begin{array}{c}\text { Teacher rates } \\
(1)\end{array}$ & $\begin{array}{c}\text { Adult employment rate } \\
\end{array}$ \\
\hline log coffee price $\times$ & -0.0182 & 0.0021 \\
coffee cultivation intensity & {$[0.0696]$} & {$[0.0022]$} \\
& & $(0.3123)$ \\
Observations & & \\
$R^{2}$ & 484 & 2204 \\
\hline \hline
\end{tabular}

Notes. Coffee cultivation intensity is measured as total coffee cultivation in 1932 (in hectares) per 100 hectares of total land area. Teacher rates refer to the number primary-school teacher per 100 children aged 5-11. This variable is at the department/year level. The results in column (2) is based on a sample limited to 1973, 1985 and 1993 census data on children in rural areas aggregated at the the department/census-year/cohort/gender level. Adult employment rate refers to the fraction family members over 16 years old who are employed at census time. All regressions are weighted by the square root of the cell sizes and include department and time fixed effects. Robust standard errors (in brackets) are clustered at the department level. Two-tailed $p$-values based on the wild cluster bootstrap- $T$ method in parentheses. There are 22 departments in column (1), and 33 departments in column(2). The number of departments differ because some departments are grouped with neighboring departments in the formal education statistics, the source for teacher data

***Significant at the 1 percent level.

**Significant at the 5 percent level.

* Significant at the 10 percent level. 
Table 7: Coffee Price Shocks and Adult Earnings

\begin{tabular}{|c|c|c|c|c|}
\hline & \multicolumn{4}{|c|}{$\begin{array}{c}\text { Dependent variable: } \\
(\log ) \text { industrial income score }\end{array}$} \\
\hline & No controls & $\begin{array}{l}\text { Add municipality } \times \\
\text { linear trends }\end{array}$ & $\begin{array}{l}\text { Add census } \times \\
\text { cohort } \\
\text { fixed effects }\end{array}$ & $\begin{array}{l}\text { Alternative } \\
\text { income } \\
\text { score }\end{array}$ \\
\hline & (1) & $(2)$ & $(3)$ & (4) \\
\hline $\begin{array}{l}\text { log school-age coffee price } \times \\
\text { coffee cultivation intensity }\end{array}$ & $\begin{array}{c}-0.0023 \\
{[0.0010]^{* *}}\end{array}$ & $\begin{array}{c}-0.0037 \\
{[0.0013]^{* * *}}\end{array}$ & $\begin{array}{c}-0.0037 \\
{[0.0013]^{* * *}}\end{array}$ & $\begin{array}{c}-0.0037 \\
{[0.0016]^{* *}}\end{array}$ \\
\hline $\begin{array}{l}\text { Observations } \\
R^{2}\end{array}$ & $\begin{array}{l}61472 \\
0.3956\end{array}$ & $\begin{array}{l}61472 \\
0.4083\end{array}$ & $\begin{array}{l}61472 \\
0.4177\end{array}$ & $\begin{array}{c}61471 \\
0.3422\end{array}$ \\
\hline & $\begin{array}{c}\text { Male } \\
\text { subsample } \\
(5)\end{array}$ & $\begin{array}{c}\text { Female } \\
\text { subsample } \\
(6)\end{array}$ & & \\
\hline $\begin{array}{l}\text { log school-age coffee price } \times \\
\text { coffee cultivation intensity }\end{array}$ & $\begin{array}{c}-0.004 \\
{[0.0015]^{* * *}}\end{array}$ & $\begin{array}{c}-0.0027 \\
{[0.0015]^{*}}\end{array}$ & & \\
\hline $\begin{array}{l}\text { Observations } \\
R^{2}\end{array}$ & $\begin{array}{l}31624 \\
0.5836\end{array}$ & $\begin{array}{l}29848 \\
0.2345\end{array}$ & & \\
\hline
\end{tabular}

Notes. School-age coffee price of the cohort born in year $t$ is the average real world coffee price observed between years $t+5$ and $t+16$. Coffee cultivation intensity is measured as total coffee cultivation in 1932 (in hectares) per 100 hectares of total municipality area. Sample restricted to 1973, 1993 and 2005 census data on individuals born between 1949 and 1983, who are 22-56 years old at the time they are observed in the census. The data are collapsed into municipality-of-birth, year-of-birth, sex and census-year cells, and the observations are weighted by the square root of the cell sizes. All regressions include controls for municipality-of-birth, year-of-birth-by-censusyear and gender fixed effects. Column (4) repeats the baseline specification, but uses an alternative income score based on the 1973 Colombian census. Columns (5)-(6) estimate the baseline specification separately for males and females. Robust standard errors (in brackets) are clustered at the municipality level. There are 531 municipalities.

*** Significant at the 1 percent level.

**Significant at the 5 percent level.

* Significant at the 10 percent level. 
Table 8: Coffee Price Shocks and Adult Earnings

(Effects by Age of Exposure)

\begin{tabular}{lccc}
\hline \hline & \multicolumn{3}{c}{$\begin{array}{c}\text { Dependent variable: } \\
(\log ) \text { industrial income score }\end{array}$} \\
\cline { 2 - 4 } & $(1)$ & $(2)$ & $(3)$ \\
\hline & & & \\
log coffee price (age: 5-11 yrs. old) $\times$ & -0.0001 & & 0.0003 \\
coffee cultivation intensity & {$[0.0007]$} & & {$[0.0007]$} \\
& & & \\
log coffee price (age: 12-16 yrs. old) $\times$ & & -0.0032 & -0.0032 \\
coffee cultivation intensity & & {$[0.0010]^{* * *}$} & {$[0.0010]^{* * *}$} \\
& & & \\
Observations & 61472 & 61472 & 61472 \\
$R^{2}$ & 0.4176 & 0.4178 & 0.4178 \\
\hline \hline
\end{tabular}

Notes. Coffee price (ages 5-11) of the cohort born in year $t$ is the average real world coffee price observed between years $t+5$ and $t+11$. Coffee price (ages 1216 ) of the cohort born in year $t$ is the average real world coffee price observed between years $t+12$ and $t+16$. Coffee cultivation intensity is measured as total coffee cultivation in 1932 (in hectares) per 100 hectares of total municipality area. Sample restricted to 1973, 1993 and 2005 census data on individuals born between 1949 and 1983, who are 22-56 years old at the time they are observed in the census. The data are collapsed into municipality-of-birth, year-of-birth, sex and census-year cells, and the observations are weighted by the square root of the cell sizes. All regressions include controls for municipality-of-birth, yearof-birth-by-census-year and gender fixed effects as well as municipality-specific linear time trends. Robust standard errors (in brackets) are clustered at the municipality level. There are 531 municipalities.

***Significant at the 1 percent level.

**Significant at the 5 percent level.

*Significant at the 10 percent level. 